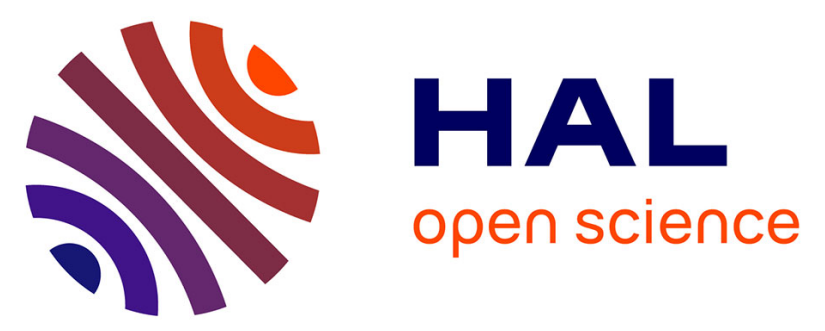

\title{
Triterpenoids from the leaves of Alphitonia xerocarpus Baill and their biological activity
}

Dima Muhammad, Nathalie Lalun, Hélène Bobichon, Elisabeth Le Magrex

Debar, Sophie C. Gangloff, Mohammed Nour, Laurence

Voutquenne-Nazabadioko

\section{To cite this version:}

Dima Muhammad, Nathalie Lalun, Hélène Bobichon, Elisabeth Le Magrex Debar, Sophie C. Gangloff, et al.. Triterpenoids from the leaves of Alphitonia xerocarpus Baill and their biological activity. Phytochemistry, 2016, 129, pp.45-57. 10.1016/j.phytochem.2016.07.005 . hal-01996335

\section{HAL Id: hal-01996335 \\ https://hal.univ-reims.fr/hal-01996335}

Submitted on 28 Oct 2021

HAL is a multi-disciplinary open access archive for the deposit and dissemination of scientific research documents, whether they are published or not. The documents may come from teaching and research institutions in France or abroad, or from public or private research centers.
L'archive ouverte pluridisciplinaire HAL, est destinée au dépôt et à la diffusion de documents scientifiques de niveau recherche, publiés ou non, émanant des établissements d'enseignement et de recherche français ou étrangers, des laboratoires publics ou privés.

\section{(1) (1) $\$$}

Distributed under a Creative Commons Attribution - NonCommercial - NoDerivatives 44.0 
Triterpenoids from the leaves of Alphitonia xerocarpus Baill and their biological activity.

Dima Muhammad $^{\mathrm{a}}$, Nathalie Lalun ${ }^{\mathrm{b}}$, Hélène Bobichon ${ }^{\mathrm{b}}$, Elisabeth Le Magrex Debar ${ }^{\mathrm{c}}$, Sophie

C. Gangloff ${ }^{\mathrm{c}}$, Mohammed Nour ${ }^{\mathrm{d}}$ and Laurence Voutquenne-Nazabadioko ${ }^{\mathrm{a} *}$

${ }^{\text {a } U M R ~ C N R S ~ 7312, ~ U n i v e r s i t e ́ ~ d e ~ R e i m s ~ C h a m p a g n e-A r d e n n e, ~ B a ̂ t . ~ 18, ~ M o u l i n ~}$ de la Housse, BP 1039, 51687 Reims, Cedex 2, France

${ }^{\mathrm{b}}$ CNRS FRE 3481, Université de Reims Champagne Ardenne, 51 rue cognacq-Jay, 51095

Reims cedex, France

${ }^{c}$ EA 4691, Laboratoire de Microbiologie, UFR de Pharmacie, 1 Rue du Maréchal Juin, 51096 Reims Cedex, France.

d Laboratoire Insulaire du Vivant et de l'Environnement (LIVE), EA 4243, Université de la Nouvelle-Calédonie, BP R4, 98851 Nouméa Cedex, Nouvelle-Calédonie

*Correspondance to: L. Voutquenne-Nazabadioko, UMR CNRS 7312, Université de Reims Champagne-Ardenne, Bât. 18, Moulin de la Housse, BP 103951687 Reims, Cedex 2, France. Tel.: +33-3-26-91-82-09; Email: laurence.nazabadioko@ univ-reims.fr 


\begin{abstract}
:
Ten previously undescribed triterpenoid saponins and a previously undescribed norlupane triterpenoid were isolated, with three known saponins, four known flavonoids, two known lupane derivatives, sitosterol and 6'-heptadecanoyl-3- $O-\beta$-D-glucopyranosylsitosterol from the leaves of Alphitonia xerocarpus (Rhamnaceae), an endemic tree of New Caledonia. The chemical structures of the purified compounds were identified by nuclear magnetic resonance and mass spectrometry. The isolated compounds were tested for their antioxidant, antityrosinase, antibacterial and cytotoxic activity. The aqueous methanol extract showed antioxidant activity (DPPH assay) due to the presence of rutin. Ceanothenic acid showed good cytotoxic activity against a $\mathrm{KB}$ cell line $\left(\mathrm{IC}_{50}=2.6 \mu \mathrm{M}\right)$ and antibacterial activity against Staphylococcus aureus and Enterococcus faecalis with MIC values of 8 and $16 \mu \mathrm{g} / \mathrm{mL}$, respectively. The previously undescribed 29-hydroxyceanothenic acid exhibited moderate cytotoxic activity $\left(\mathrm{IC}_{50}=10 \mu \mathrm{M}\right)$, good antibacterial activity against $S$. aureus (MIC $=4$ $\mu \mathrm{g} / \mathrm{mL}$ ) and moderate antibacterial activity against E. faecalis $(\mathrm{MIC}=16 \mu \mathrm{g} / \mathrm{mL}$ ).
\end{abstract}

Keywords: Alphitonia xerocarpus; Rhamnaceae; leaves; triterpenoids; secodammarane; norlupane; flavonoids 


\section{INTRODUCTION}

New Caledonia is well known for its high biodiversity with a global endemic area of $74.3 \%$.

This high endemicity is partly due to the multiplicity of geological substrates, with one-third of the total area covered by ultramafic rocks. Erosion and alteration of these rocks have led to nutrient depletion and soil enrichment with heavy metals resulting in the development of a unique flora. In New Caledonia, the Rhamnaceae family is represented by a half-dozen genera and a total of ten species, of which half are endemic. The genus Alphitonia is the best represented, with three endemic species (A. neocaledonica (Schltr.) Guillaumin, $A$. xerocarpus Baill. and A. erubescens Baill.) (Guillaumin, 1948). This genus is composed of approximately 20 species growing in tropical regions of Southeast Asia, Oceania and Polynesia (Correa et al., 2010, Richardson et al., 2000). A range of phenolic compounds has already been identified from various Alphitonia species (Branch et al., 1972, Guise et al., 1962, Jou et al., 2004). More precisely, flavonoids have been identified in the leaves (Lin et al., 1995) and fruit (Muhammad et al., 2015) of A. neocaledonica. Lupane triterpenoids, including ceanothic acid, betulin, betulinic acid and alphitolic acid, have also been detected in several Alphitonia species (Branch et al., 1972, Guise et al., 1962, Jou et al., 2004, Muhammad et al., 2015, Setzer et al., 2004) and showed in vitro cytotoxic, antiinflammatory, and antimicrobial activity (Dzuback et al., 2006). In addition, various dammarane saponins, including derivatives of jujubogenin (Kimura et al., 1981, Renault et al., 1997) and 16,17-secodammarane (Yoshikawa et al., 1996) have been isolated from the Rhamnaceae and Alphitonia species (Li et al., 1994).

Alphitonia xerocarpus Baill (Rhamnaceae) is a small forest tree growing on the mountains in the south of New Caledonia at an altitude of 800-900 meters (Baillon, 1876). The leaves are tough, completely hairless, alternate and elliptical $(3 \times 6 \mathrm{~cm})$ with rounded corners (Schlechter, 1907). In a continuation of the study of New-Caledonian Alphitonia species (Muhammad et al., 2015), we investigated the secondary metabolite profile of Alphitonia xerocarpus leaves. In this study, eleven previously undescribed (1-11) and eleven known (12-22) compounds were isolated. Flavonoids have been reported to possess antioxidant (Ko et al. 2011) and antityrosinase activity (Parvez et al. 2007) while triterpenoids from Alphitonia species have shown cytotoxic and antimicrobial activity (Dzuback et al., 2006). In this study, the radical scavenging ability of the extracts was determined. The tyrosinase inhibitory activity of the flavonoids as well as the cytotoxic activity (against KB cells) and the antibacterial activity of some of the triterpenoids were also investigated. 


\section{Results and discussion}

The powdered leaves of Alphitonia xerocarpus were macerated and extracted successively with petroleum ether and EtOAc and then refluxed with a mixture of $\mathrm{CH}_{3} \mathrm{OH}-\mathrm{H}_{2} \mathrm{O}$ (8:2) to give three extracts. The EtOAc extract was fractionated by silica gel and $\mathrm{RP}_{-} \mathrm{C}_{18}$ column chromatography to give a previously undescribed norlupane triterpenoid (1) along with the known betulin (20) (Guo et al., 2011, Siddiqui et al., 1988), ceanothenic acid (12) (Jou et al., 2004), the major component (6 \%), sitosterol (21) (Kovganko et al., 2000, McCarthy et al., 2005), and 6'-heptadecanoyl-3-O- $\beta$-D-glucopyranosylsitosterol (22) (Gutierrez-Lugo et al., 2005).

The aqueous methanol extract was subjected to multiple chromatographic steps over silica gel and RP- $\mathrm{C}_{18}$ yielding ten previously undescribed compounds (2-11) with three known saponins, 3- $O$ - $\alpha$-L-rhamnopyranosyl-( $1 \rightarrow 2)$-[4- $O$-(sodium sulfonato)- $\beta$-D-glucopyranosyl$(1 \rightarrow 3)$ ]- $\alpha$-L-arabinopyranosyljujubogenin $(\mathbf{1 3})$, the sodium salt of a kwown saponin (Maciuk et al., 2004), 3-O- $\alpha$-L-rhamnopyranosyl-( $1 \rightarrow 2)$-[ $\beta$-D-glucopyranosyl-( $1 \rightarrow 3)]-\alpha$-Larabinopyranosyljujubogenin (14) (Okamura et al., 1981) and 3-O- $\beta$-D-glucopyranosyl$(1 \rightarrow 2)-\beta$-D-glucopyranosyl-( $1 \rightarrow 3)$-[ $\alpha$-L-rhamnopyranosyl- $(1 \rightarrow 2)]-\alpha$-Larabinopyranosyljujubogenin (15) (Wang et al., 2013) and four known flavonoids, rutin (16) (Lallemand et al., 1977, Li et al., 2008), kaempferol 3-O-rutinoside (17) (Park et al., 2008), 3$O$ - $\alpha$-L-arabinopyranosyl-( $1 \rightarrow 2)$ - $\alpha$-L-rhamnopyranosylkaempferol (18) (Muzitano et al., 2006), and 3-O- $\beta$-D-xylopyranosyl-( $1 \rightarrow 2)$ - $\alpha$-L-rhamnopyranosylkaempferol (19) (Bilia et al., 1996, Soicke et al., 1990) (Figure 1). Rutin was the major component of this extract (3.4\%) and was isolated from the leaves in $1.16 \%$ yield.

All compounds were identified by extensive spectroscopic methods including $1 \mathrm{D}-\left({ }^{1} \mathrm{H}\right.$ and $\left.{ }^{13} \mathrm{C}\right)$ and 2D-NMR (COSY, J-modulated HSQC, HMBC and NOESY) experiments as well as HRESI-MS analysis and by comparison with literature spectral data for the known compounds. Acid hydrolysis of the aqueous methanol extract afforded four sugar units in the aqueous layer, identified by HPLC analysis on a chiral column (Lavaud et al., 2015, Lopes and Gaspar, 2008), as D-glucose (Glc), D-xylose (Xyl), L-arabinose (Ara) and L-rhamnose (Rha).

Compound 1 was obtained as a white amorphous powder with the molecular formula $\mathrm{C}_{29} \mathrm{H}_{42} \mathrm{O}_{5}$ [HRESIMS: $m / z$ 493.2936 ([M + Na] $]^{+}$, calcd 493.2930]. The ${ }^{1} \mathrm{H}$ NMR spectrum of 1 showed the presence of four tertiary methyl groups $\left(\delta_{\mathrm{H}} 0.94,1.01(6 \mathrm{H})\right.$, and 1.08), an exomethylene and a disubstituted double bond [ $\delta_{\mathrm{H}} 4.95(\mathrm{brs}), 4.99(d, J=1.5 \mathrm{~Hz}), 5.43$ (d, $J=5.7 \mathrm{~Hz})$, and $5.96(d, J=5.7 \mathrm{~Hz})]$, and an oxymethylene group $\left(\delta_{\mathrm{H}} 4.05\right.$, and 4.16, each $d$, $J=14.8 \mathrm{~Hz}$ ). Its ${ }^{13} \mathrm{C}$ NMR spectrum exhibited signals for 29 carbons (Table S1), including two 
carboxyl groups ( $\delta_{\mathrm{C}} 178.6$ and 179.3), two double bonds $\left(\delta_{\mathrm{C}} 107.7,140.1,141.7\right.$, and 155.5), and an oxygenated methylene $\left(\delta_{\mathrm{C}} 64.9\right)$. The spectroscopic data were similar to those of ceanothenic acid (12) (Jou et al., 2004). The only difference is in the presence of a hydroxyl group attached to C-29. This was readily confirmed by $\mathrm{HMBC}$ correlations from $\mathrm{H}_{2}-30$ to C29 and from $\mathrm{H}_{2}-29$ and $\mathrm{H}_{2}-30$ to C-19 ( $\left.\delta_{\mathrm{C}} 44.6\right)$ and C-20 $\left(\delta_{\mathrm{C}} 155.5\right)$, and by a long range ${ }^{4} J_{\mathrm{H}-}$ ${ }_{\mathrm{H}} \mathrm{COSY}$ correlation from $\mathrm{H}_{2}-29$ to the exomethylene protons $\mathrm{H}_{2}-30$. Full assignments of the proton and carbon resonances of compound 1 were achieved by analysis of the COSY, $J$ modulated HSQC and HMBC spectra. Thus compound $\mathbf{1}$ is 29-hydroxyceanothenic acid. Compound 2 had the molecular formula $\mathrm{C}_{60} \mathrm{H}_{96} \mathrm{O}_{30}$ [HRESIMS: $m / z 1319.5892[\mathrm{M}+\mathrm{Na}]^{+}$, calcd for $\left.\mathrm{C}_{60} \mathrm{H}_{96} \mathrm{O}_{30} \mathrm{Na}, 1319.5884\right]$. The ${ }^{1} \mathrm{H}$ NMR spectrum of the aglycone of $\mathbf{2}$ showed signals of a lupane triterpenoid characterized by six tertiary methyl groups $\left(\delta_{\mathrm{H}} 0.94,1.01\right.$, $1.02,1.09,1.10$ and 1.71), an exomethylene group ( $\delta_{\mathrm{H}} 4.61$ and 4.73 , each $b r s$ ), and an oxymethine $\left(\delta_{\mathrm{H}} 4.10, \mathrm{brs}\right)$. Its ${ }^{13} \mathrm{C}$ NMR spectrum exhibited 30 carbon signals including two carboxyl groups ( $\delta_{\mathrm{C}} 174.5$ and 177.4), an exomethylene ( $\delta_{\mathrm{C}} 108.8$ and 150.4$)$, and an oxymethine $\left(\delta_{\mathrm{C}} 84.5\right)$ (Table 1$)$. Analysis of the COSY, $J$-modulated HSQC and HMBC spectra and comparison of these data with the literature revealed that the aglycone was ceanothic acid (Jou et al., 2004). The shielded chemical shift of C-28 suggested a monodesmosidic saponin. Analysis of the ${ }^{1} \mathrm{H}$ and ${ }^{13} \mathrm{C}$ NMR spectra of 2 revealed the presence of five anomeric protons at $\delta_{\mathrm{H}} 5.64(d, J=8.3 \mathrm{~Hz}), 5.04(d, J=7.6 \mathrm{~Hz}), 4.71(d, J=7.8 \mathrm{~Hz}), 4.68$ $(d, J=7.8 \mathrm{~Hz})$ and $4.58(d, J=7.8 \mathrm{~Hz})$ correlated in the $J$-modulated HSQC spectrum with anomeric carbons at $\delta_{\mathrm{C}} 91.9,101.2,103.3,103.6$ and 103.6, respectively (Table 1). Analysis of the COSY, TOCSY and $J$-modulated HSQC spectra of $\mathbf{2}$ allowed complete assignment of the five glycosidic proton and carbon systems leading to five $\beta$-D-glucopyranose units (Agrawal, 1992) (Table 1). The $\beta$-anomeric configurations, deduced from the large coupling constant $J_{\mathrm{H}-1-\mathrm{H}-2}$ of 7-8 Hz and the ${ }^{13} \mathrm{C}$ NMR chemical shift (Agrawal, 1992), were confirmed by the rOe effects observed between the $\alpha$-axial protons $\mathrm{H}-1 / \mathrm{H}-3$ and $\mathrm{H}-1 / \mathrm{H}-5$ in each sugar unit. The four anomeric carbons between $\delta_{\mathrm{C}} 101-104$ indicated that these carbons were involved in ether linkages while the anomeric carbon at $\delta_{\mathrm{C}} 91.9\left(\delta_{\mathrm{H}} 5.64\right)$ is linked by an ester bond. This was confirmed by the HMBC correlations between Glc-H-1' $(\delta 5.64)$ and C-28 ( $\delta$ $174.5)$. Other HMBC correlations between Glc-H-1" ( $\delta$ 5.04) and Glc-C-2' ( $\delta 75.7)$, Glc-H-1"' ( $\delta$ 4.71) and Glc-C-2" ( $\delta$ 81.3), Glc-H-1"' ( $\delta$ 4.58) and Glc-C-3" ( $\delta$ 86.6); and Glc-H-1"'"' $\delta$ 4.68) and Glc-C-6" ( $\delta$ 68.7) revealed the sequence of the pentasaccharide moiety with the second glucose unit trisubstituted in positions C-2", C-3" and C-6". Thus the structure of 
saponin 2 was deduced as $28-O-\beta$-D-glucopyranosyl-( $1 \rightarrow 6)$-[ $\beta$-D-glucopyranosyl- $(1 \rightarrow 3)]$ - $[\beta$ D-glucopyranosyl-( $(1 \rightarrow 2)]-\beta$-D-glucopyranosyl-( $1 \rightarrow 2)-\beta$-D-glucopyranosylceanothic acid. Compound 3 has a molecular formula $\mathrm{C}_{42} \mathrm{H}_{68} \mathrm{O}_{14}$ [HRESIMS: $\mathrm{m} / z 819.4529[\mathrm{M}+\mathrm{Na}]^{+}$; calcd for $\left.\mathrm{C}_{42} \mathrm{H}_{68} \mathrm{O}_{14} \mathrm{Na}, 819.4507\right]$. The ${ }^{1} \mathrm{H}$ NMR spectrum of the aglycone of $\mathbf{3}$ showed signals of a dammarane triterpenoid, characterized by seven tertiary methyl groups $\left(\delta_{\mathrm{H}} 0.87,0.91,1.06\right.$, $1.07,1.21,1.65$ and 1.71$)$, a vinyl proton $\left(\delta_{\mathrm{H}} 5.22, t q, J=7.3,0.7 \mathrm{~Hz}\right)$, two oxygen-bearing methines $\left[\delta_{\mathrm{H}} 3.19(d d, J=7.3,4.8 \mathrm{~Hz}), 4.14(t, J=6.6 \mathrm{~Hz})\right]$, and an oxygen-bearing methylene group $\left[\delta_{\mathrm{H}} 3.96(d d, J=8.3,1.6 \mathrm{~Hz}), 3.99(d, J=8.3 \mathrm{~Hz})\right]$. Its ${ }^{13} \mathrm{C}$ NMR and $J$-modulated HSQC spectra exhibited signals for seven methyl groups [ $\delta_{\mathrm{C}} 15.4$ (C-19), 15.5 (C-29), 16.5 (C-27), 17.8 (C-30), 22.1 (C-21), 24.5 (C-26), and 27.0 (C-28)], two oxymethine carbons [ $\delta_{\mathrm{C}} 89.1$ and 94.1], two olefinic carbons [ $\delta_{\mathrm{C}} 120.7$ (C-24) and $\left.132.6(\mathrm{C}-25)\right]$, an oxymethylene carbon $\left[\delta_{\mathrm{C}}\right.$ 65.4], an acetal carbon [ $\left.\delta_{\mathrm{C}} 117.5\right]$ and a quaternary oxygenated carbon [ $\left.\delta_{\mathrm{C}} 75.1\right]$ (Table 2). These data suggested that compound $\mathbf{3}$ had the same genin as jujuboside IV (Wang et al., 2013). Analysis of the COSY, $J$-modulated HSQC and HMBC spectra confirmed its identity as 16 $\beta, 22 R: 16 \alpha, 18$-diepoxydammar-24-ene-3 $\beta, 20 R$-diol* (Maciuk et al., 2004, Wang et al., 2013). The deshielded nature of C-3 ( $\left.\delta_{C} 89.1\right)$ suggested a monodesmosidic saponin. The ${ }^{1} \mathrm{H}$ and ${ }^{13} \mathrm{C}-\mathrm{NMR}$ spectra revealed the presence of two sugar units with anomeric protons at $\delta_{\mathrm{H}}$ $4.42(d, J=7.8 \mathrm{~Hz})$ and $4.35 \mathrm{ppm}(d, J=7.8 \mathrm{~Hz})$ and the corresponding carbons at $\delta_{\mathrm{C}} 104.8$ and 106.7 (Table 1). Analysis of COSY and $J$-modulated HSQC spectra allowed assignment of two $\beta$-D-glucopyranose units, one terminal $\left(\delta_{\mathrm{H}} 4.42\right)$ and the second substituted on the hydroxyl at C-6' ( $\left.\delta_{C} 69.9\right)$ (Agrawal, 1992). The HMBC correlations between Glc-H-1" $(\delta$ 4.42)/Glc-C-6', Glc-H-1' ( $\delta$ 4.35)/C-3 ( $\delta 89.1)$, and the rOe correlations between Glc-H1"/Glc-H-6', Glc-H-1'/H-3 revealed the linkage of the disaccharide moiety. Thus, the structure of saponin 3 was identified as 3-O- $\beta$-D-glucopyranosyl-( $1 \rightarrow 6)-\beta$-D-glucopyranosyl16/22R:16 $\alpha, 18$-diepoxydammar-24-ene-3 $\beta, 20 R$-diol (Figure 1).

Comparison of the ${ }^{1} \mathrm{H}$ NMR and ${ }^{13} \mathrm{C}$ NMR spectra of compounds 4-5 with the known compounds 13-15 indicated that they all possess the same genin, jujubogenin, glycosylated at C-3 ( $\delta_{\mathrm{C}}$ 89.6) (Maciuk et al., 2004).

*The correct biogenetic numbering system for dammaranes, as listed in the Dictionary of Natural Products, is used in this paper (Connolly and Hill, 1992). Methyl groups 18 and 30 are wrongly numbered in the paper by Wang et al. 2013 and many other articles. Thus, C-18 and C-30 should be interchanged to be conforming to the IUPAC nomenclature. 
Compounds 4 and 5 were isolated as a mixture 6:4, inseparable by chromatography on RP-18 and silica gel. They had the same molecular formula $\mathrm{C}_{58} \mathrm{H}_{94} \mathrm{O}_{26}$, [HRESIMS: $m / z$ 1229.5923 $[\mathrm{M}+\mathrm{Na}]^{+}$; calcd for $\left.\mathrm{C}_{58} \mathrm{H}_{94} \mathrm{O}_{26} \mathrm{Na}, 1229.5931\right]$ and contained 132 additional molecular weight units relative to jujuboside I (15), suggesting the presence of an additional pentose unit (Wang et al., 2013). The ${ }^{1} \mathrm{H}$ - and ${ }^{13} \mathrm{C}-\mathrm{NMR}$ spectra of $\mathbf{4}$ and $\mathbf{5}$ were very similar to those of jujuboside I (15) with signals assignable to jujubogenin and five sugars moieties. Five anomeric signals were observed in ${ }^{1} \mathrm{H}-\mathrm{NMR}$ and ${ }^{13} \mathrm{C}$-NMR spectra at $\delta_{\mathrm{H}} 4.34(d, J=7.5 \mathrm{~Hz}$, $\left.\delta_{\mathrm{C}} 104.4\right), 4.39\left(d, J=6.5 \mathrm{~Hz}, \delta_{\mathrm{C}} 104.7\right), 4.69\left(d, J=7.8 \mathrm{~Hz}, \delta_{\mathrm{C}} 101.6\right), 4.89\left(d, J=6.9 \mathrm{~Hz}, \delta_{\mathrm{C}}\right.$ $102.7)$ and $5.26\left(d, J=1.5 \mathrm{~Hz}, \delta_{\mathrm{C}} 100.8\right)$ for compound 4 and at $\delta_{\mathrm{H}} 4.36\left(d, J=6.8 \mathrm{~Hz}, \delta_{\mathrm{C}}\right.$ $104.1), 4.39\left(d, J=6.5 \mathrm{~Hz}, \delta_{\mathrm{C}} 104.7\right), 4.69\left(d, J=7.8 \mathrm{~Hz}, \delta_{\mathrm{C}} 101.6\right), 4.89\left(d, J=6.9 \mathrm{~Hz}, \delta_{\mathrm{C}}\right.$ 102.6) and $5.31\left(d, J=1.5 \mathrm{~Hz}, \delta_{\mathrm{C}} 100.6\right)$ for compound 5 (Table 3). Analysis of COSY, TOCSY, $J$-modulated HSQC, and HMBC experiments identified four sugars moieties as in jujuboside I (15) (Wang et al., 2013), two $\beta$-D-glucopyranoses from the anomeric protons at $\delta_{\mathrm{H}} 4.69$ and 4.89 , one substituted at position C-6"' ( $\left.\delta_{\mathrm{C}} 68.0\right)$, a terminal $\alpha$-L-rhamnopyranose $\left(\delta_{\mathrm{H}} 5.26\right)$ with its methyl signal at $\delta_{\mathrm{H}} 1.25(\mathrm{~d}, J=6.2 \mathrm{~Hz})$ and $\delta_{\mathrm{C}} 16.8$, and an $\alpha$-Larabinopyranose $\left(\delta_{\mathrm{H}} 4.39\right)$ disubstitued at positions C-2' $\left(\delta_{\mathrm{C}} 74.7\right)$ and C-3' $\left(\delta_{\mathrm{C}} 81.1\right)$ (Agrawal, 1992) (Table 3). The supplementary pentose unit was identified as a $\beta$-Dxylopyranose in compound $\mathbf{4}$ and an $\alpha$-L-arabinopyranose in 5 (Agrawal, 1992). These sugars were attached to the $\beta$-D-glucopyranose at C-6"'" as suggested by its deshielded signal $\left(\delta_{\mathrm{C}}\right.$ 68.0) (Table 3). The interglycosidic linkage was established by the HMBC correlations observed between Xyl-H-1"'"/Glc-C-6"'", Glc-H-1'"'/Glc-C-2"', Glc-H-1"'/Ara-C-3', Rha-H1"/Ara-C-2' , and Ara-H-1'/C-3 for compound 4 and between Ara-H-1"'"/Glc-C-6"', Glc-H1"'/Glc-C-2"', Glc-H-1"'/Ara-C-3', Rha-H-1"/Ara-C-2', and Ara-H-1'/C-3 for compound 5. Thus, the structure of compound $\mathbf{4}$ is the previously undescribed 3-O- $\beta$-D-xylopyranosyl$(1 \rightarrow 6)$ - $\beta$-D-glucopyranosyl-( $1 \rightarrow 2)$ - $\beta$-D-glucopyranosyl-( $1 \rightarrow 3)$-[ $\alpha$-L-rhamnopyranosyl$(1 \rightarrow 2)]$ - $\alpha$-L-arabinopyranosyljujubogenin, and compound $\mathbf{5}$ is the previously undescribed 3$O$ - $\alpha$-L-arabinopyranosyl-( $1 \rightarrow 6)-\beta$-D-glucopyranosyl-( $1 \rightarrow 2)$ - $\beta$-D-glucopyranosyl- $(1 \rightarrow 3)$ - $[\alpha$-L-

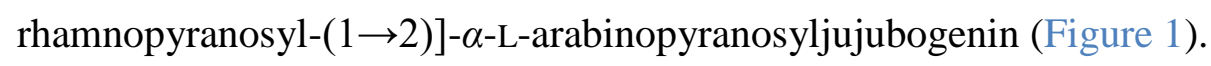

Compound 6, a white amorphous powder, has the molecular formula $\mathrm{C}_{42} \mathrm{H}_{68} \mathrm{O}_{15}$ [HRESIMS $m / z$ 835.4463 [M+Na] ${ }^{+}$: calcd for $\left.\mathrm{C}_{42} \mathrm{H}_{68} \mathrm{O}_{15} \mathrm{Na}, 835.4456\right]$. The ${ }^{1} \mathrm{H}-$ and ${ }^{13} \mathrm{C}-\mathrm{NMR}$ spectra of the aglycone were very similar to those of jujubogenin. The main difference was the presence of an additional secondary hydroxyl group $\left[\delta_{\mathrm{H}} 3.01(\mathrm{~s}), \delta_{\mathrm{C}} 73.8\right]$ (Table 2) which was readily located at C-22 by a COSY correlation between H-22 and H-23 and by HMBC correlations from H-22 to C-17, C-20, C-21, C-23 and C-24. The small coupling constant between H-22 
and $\mathrm{H}-23$ and the rOe effect observed between the equatorial Me-21 and H-22 indicated that the C-22 hydroxyl was $\alpha$-oriented (axial) (Figure 2). Thus the genin of compound $\mathbf{6}$ is the previously undescribed $22 \alpha$-hydroxyjujubogenin, which is glycosylated at the C-3 position $\left(\delta_{\mathrm{C}} 89.1\right)$. The ${ }^{1} \mathrm{H}-,{ }^{13} \mathrm{C}-\mathrm{NMR}, \mathrm{COSY}$ and $J$-modulated HSQC spectra revealed the presence of a terminal $\beta$-D-glucopyranose and a C-6' substituted $\beta$-D-glucopyranose as in compound $\mathbf{3}$ (Agrawal, 1992) (Table 4). The HMBC correlations between Glc-H-1"/Glc-C-6' and Glc-H$1 ' / \mathrm{C}-3$ confirmed the linkage of the disaccharide moiety. Thus, saponin 6 is $3-O-\beta$-Dglucopyranosyl-(1 $\rightarrow 6)-\beta$-D-glucopyranosyl-22 $\alpha$-hydroxyjujubogenin (Figure 1).

The ${ }^{1} \mathrm{H}-\mathrm{NMR}$ and ${ }^{13} \mathrm{C}-\mathrm{NMR}$ spectra of compound 7 were very similar to those of compound $\mathbf{6}$ with the same disaccharide chain attached to $\mathrm{C}-3$ of $22 \alpha$-hydroxyjujubogenin but they indicated that it was a 1:1 mixture of esters at C-6" (Table 4). Both components of the mixture possessed the same molecular formula $\mathrm{C}_{51} \mathrm{H}_{74} \mathrm{O}_{17}$ [HRESIMS: $\mathrm{m} / \mathrm{z} 981.4822\left[\mathrm{M}+\mathrm{Na}{ }^{+}\right.$; calcd for $\left.\mathrm{C}_{51} \mathrm{H}_{74} \mathrm{O}_{17} \mathrm{Na}, 981.4824\right]$. The ${ }^{1} \mathrm{H}$ - and ${ }^{13} \mathrm{C}-\mathrm{NMR}$ spectra readily revealed the presence of $Z$ - and E-p-coumaroyl groups (E1 Sohly et al., 1999) (Table 4). The HMBC correlations from the ester carbonyl at $\delta_{\mathrm{C}} 166.7$ to the $Z$-vinyl protons [ $\delta_{\mathrm{H}} 5.84$ and 6.91 (each $d, J=12.8 \mathrm{~Hz}$ )] and to GlcH-6" [4.24 (dd, $J=11.9,5.8 \mathrm{~Hz})$ and $4.53(d d, J=11.9,2.1 \mathrm{~Hz})]$ indicated that the structure of compound 7a is 3- $O$-[6- $O$-(Z-p-coumaroyl- $\beta$-D-glucopyranosyl- $(1 \rightarrow 6)]-\beta$-D-glucopyranosyl$22 \alpha$-hydroxyjujubogenin. Other HMBC correlations from the ester carbonyl at $\delta_{\mathrm{C}} 167.7$ to the $E$-vinyl protons $\left[\delta_{\mathrm{H}} 6.40\right.$ and 7.68 (each $d, J=16.1 \mathrm{~Hz}$ )] and to Glc-H-6" [ $\delta_{\mathrm{H}} 4.29(d d, J=11.9$, $5.7 \mathrm{~Hz})$ and $4.60(d d, J=11.9,2.2 \mathrm{~Hz})]$ confirmed that the structure of compound $7 \mathbf{b}$ is $3-O-[6-$ $O$-(E-p-coumaroyl- $\beta$-D-glucopyranosyl-( $1 \rightarrow 6)]-\beta$-D-glucopyranosyl-22 $\alpha$-hydroxyjujubogenin (Figure 1).

The ${ }^{1} \mathrm{H}-\mathrm{NMR}$ and ${ }^{13} \mathrm{C}-\mathrm{NMR}$ spectra of compound $\mathbf{8}$ were very similar to those of compound $\mathbf{7}$ and again showed that it was a mixture of compounds esterified at position C-6" (Table 4). Both components had the same molecular formula $\mathrm{C}_{53} \mathrm{H}_{78} \mathrm{O}_{19}$ [HRESIMS: $m / z 1041.5024[\mathrm{M}+\mathrm{Na}]^{+}$; calcd for $\left.\mathrm{C}_{53} \mathrm{H}_{78} \mathrm{O}_{19} \mathrm{Na}, 1041.5035\right]$. In the ${ }^{1} \mathrm{H}-\mathrm{NMR}$ and COSY spectra, signals for two sets of two methoxy groups $\left[\delta_{\mathrm{H}} 3.92(s, 6 \mathrm{H})\right.$ and $\left.\delta_{\mathrm{H}} 3.89(s, 6 \mathrm{H})\right]$, two aromatic protons $\left[\delta_{\mathrm{H}} 6.98(s\right.$, $2 \mathrm{H})$ and $\delta_{\mathrm{H}} 7.33(s, 2 \mathrm{H})$ ], two vicinal vinyl protons [ $E \delta_{\mathrm{H}} 6.47$ and 7.67 (each $d, J=15.9 \mathrm{~Hz}$ ) and $Z \delta_{\mathrm{H}} 5.89$ and 6.90 (each $d, J=13.0 \mathrm{~Hz}$ )] (Table 4) suggested the presence of sinapoyl esters in a ratio of 1:3 (Z:E). The ${ }^{13} \mathrm{C}-\mathrm{NMR}$ and HSQC spectra exhibited signals for two ester carbonyls [ $\delta_{\mathrm{C}} 166.6$ and 167.6], four vinyl carbons $\left[\delta_{\mathrm{C}} 114.3,115.3,144.7\right.$ and 146.0], two quaternary aromatic carbons [ $\delta_{\mathrm{C}} 125.1$ and 125.5], six oxygenated aromatic carbons [ $\delta_{\mathrm{C}} 137.7,138.4,147.2$ $(2 \mathrm{C})$ and $148.1(2 \mathrm{C})]$, four aromatic methines $\left[\delta_{\mathrm{C}} 105.1(2 \mathrm{C})\right.$, and $\left.108.7(2 \mathrm{C})\right]$ and four methoxy groups [ $\delta_{\mathrm{C}} 55.5(2 \mathrm{C})$, and $55.4(2 \mathrm{C})$ ], consistent with a mixture of $Z$ - and $E$ - sinapoyl groups 
(Xu et al., 2010) (Table 4). HMBC correlations as above confirmed that compound 8 was a mixture of 3-O-[6-O-(E,Z)-sinapoyl- $\beta$-D-glucopyranosyl- $(1 \rightarrow 6)]-\beta$-D-glucopyranosyl-22 $\alpha$ hydroxyjujubogenin (Figure 1).

Analysis of 1D and 2D NMR spectra of compounds 9-11 indicated that they were dammarane $O$-glycosides with identical disaccharides attached to C-3 of the genin. They therefore differed in the aglycone part. The three compounds were identified as 16,17-seco-dammarane derivatives, arising from a cleavage of the C-16-C-17 bond, migration of $\mathrm{CH}_{3}-21$ from C-20 to C-17 and oxidation of C-20 and C-26 (Yoshikawa et al., 1996).

Compound 9 had a molecular formula $\mathrm{C}_{42} \mathrm{H}_{64} \mathrm{O}_{15}$ [HRESIMS: $m / z 831.4138[\mathrm{M}+\mathrm{Na}]^{+}$, calcd for $\mathrm{C}_{42} \mathrm{H}_{64} \mathrm{O}_{15} \mathrm{Na}$, 831.4143]. The ${ }^{1} \mathrm{H}-\mathrm{NMR}$ spectrum of the aglycone showed signals for four tertiary methyls $\left[\delta_{\mathrm{H}} 0.88,0.90,1.05\right.$, and 1.08$]$, a secondary methyl $\left[\delta_{\mathrm{H}} 1.07(d, J=4.0 \mathrm{~Hz})\right]$ a vinyl methyl $\left[\delta_{\mathrm{H}} 1.90(\mathrm{brs})\right]$, a vinyl proton $\left[\delta_{\mathrm{H}} 7.32(d t, J=6.2,1.7 \mathrm{~Hz})\right]$, two oxygen-bearing methine protons $\left[\delta_{\mathrm{H}} 3.20(d d, J=11.7,3.6 \mathrm{~Hz})\right.$ and $\left.5.39(\mathrm{~m})\right]$, and two deshielded oxymethylene protons $\left[\delta_{\mathrm{H}} 4.39\right.$ and 4.49 (each $d, J=10.6 \mathrm{~Hz}$ )]. The ${ }^{13} \mathrm{C}-\mathrm{NMR}$ spectrum revealed six methyl groups $\left[\delta_{\mathrm{C}} 9.1(\mathrm{C}-27), 10.4\right.$ (C-21), 15.1 (C-19), 15.6 (C-29), 17.5 (C-30), and 26.9 (C-28)], two ester/lactone carbonyl groups [ $\delta_{\mathrm{C}} 174.8$ (C-26), $\left.178.2(\mathrm{C}-16)\right]$, a ketone [ $\left.\delta_{\mathrm{C}} 209.3(\mathrm{C}-20)\right]$, two olefinic carbons [ $\delta_{\mathrm{C}} 129.4(\mathrm{C}-25)$ and $149.6(\mathrm{C}-24)$ ], an oxymethylene carbon $\left[\delta_{\mathrm{C}} 70.0(\mathrm{C}-18)\right]$ and two oxymethine carbons $\left[\delta_{\mathrm{C}} 88.5(\mathrm{C}-3)\right.$ and $\left.77.8(\mathrm{C}-23)\right]$ (Table 5). These data show that compound 9 is virtually the same as hovenidulcioside A1 and differs only in the presence of a ketone instead of an acetate at C-20 (Yoshikawa et al., 1995; Yoshikawa et al., 1996). HMBC correlations from H-22, H-17, H-13 and Me-21 to the ketone confirmed its position at C-20. The deshielded chemical shifts of C-17 $\left(\delta_{\mathrm{C}} 45.8\right)$ and C-22 $\left(\delta_{\mathrm{C}}\right.$ 43.3), relative to hovenidulciogenin $\mathrm{A}\left(\delta_{\mathrm{C}-17} 37.7\right.$ and $\left.\delta_{\mathrm{C}-22} 35.0\right)$ (Yoshikawa et al., 1995) are due to the presence of the $\mathrm{C}-20$ ketone. They are in good agreement with the data for the C-20 of 16,17-seco-dammarane guoanogenine B (Kennelly et al., 1993). ROe effects between the $\beta$-axial Me-29/Me-19, Me-19/Me-30, Me-30/H-13 and between the $a$-axial H-3/H-5 and H5/H-9 confirm the expected stereochemistry (Figure 3). The crystal data of hovenidulcioside A1 (Yoshikawa et al., 1995) suggest rOes from H-18a to Me-21 and from H-13 to H-17. The fact that these are observed supports the assumption that compound $\mathbf{9}$ has the same side chain stereochemistry as the hovenidulciosides. Definitive proof will require an X-ray crystal structure. The $\beta$-configuration of $\mathrm{H}-23$ was assigned from the rOe effect between $\mathrm{H}_{\mathrm{a}}-22$ and $\mathrm{H}-23$ and by comparison of the ${ }^{13} \mathrm{C}$ NMR data of C-23 $\left(\delta_{\mathrm{C}} 77.8\right)$ with those of hovenidulcioside A1 (Yoshikawa et al., 1995). Thus the genin of compound 9 is the previously undescribed $(3 \beta, 17 R, 23 R) 3$-hydroxy-20-oxo-16,17-seco-21(20 $\rightarrow 17)$ - 
abeodammar-24-ene-16,18:26,23-diolide, glycosylated at C-3 $\left(\delta_{\mathrm{C}} 88.5\right)$. The ${ }^{1} \mathrm{H}-,{ }^{13} \mathrm{C}-\mathrm{NMR}$, COSY and $J$-modulated HSQC spectra revealed the presence of the same disaccharide unit as in hovenidulcioside A1, attached at C-3 (Table 5). Thus saponin 9 is the previously

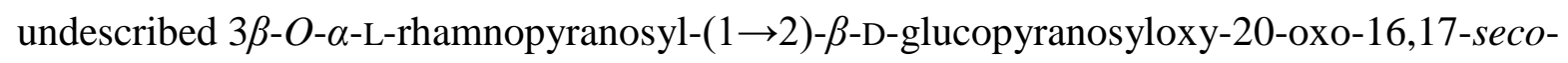
$21(20 \rightarrow 17)$-abeodammar-24-ene-16,18:26,23-diolide (Figure 1).

Compounds $\mathbf{1 0}$ and $\mathbf{1 1}$ (Figure 1) have the same molecular formula $\mathrm{C}_{42} \mathrm{H}_{66} \mathrm{O}_{15}$ [HRESIMS: $\mathrm{m} / \mathrm{z}$ $833.4286[\mathrm{M}+\mathrm{Na}]^{+}$; calcd for $\left.\mathrm{C}_{42} \mathrm{H}_{66} \mathrm{O}_{15} \mathrm{Na}, 833.4299\right]$ corresponding to dihydro-derivatives of compound 9. Analysis of $1 \mathrm{D}\left({ }^{1} \mathrm{H},{ }^{13} \mathrm{C}\right)$ and 2D NMR spectra (COSY, J-modulated HSQC, and HMBC) indicated that they have the same disaccharide unit as compound 9 and differ only in the terminal $\gamma$-lactone of the aglycone. The vinyl carbons have been replaced by two shielded carbons at $\delta_{\mathrm{C}} 33.7(\mathrm{C}-25)$ and $34.5(\mathrm{C}-24)$ in compound 10, and at $\delta_{\mathrm{C}} 35.5(\mathrm{C}-25)$ and $36.2(\mathrm{C}-$ $24)$ in compound 11. The C-27 methyl singlet has been replaced by a doublet at $\delta_{\mathrm{H}} 1.27(d, J=$ $7.3 \mathrm{~Hz}$ ) (Table 5). These data indicate that both compounds $\mathbf{1 0}$ and $\mathbf{1 1}$ contain a saturated terminal $\gamma$-lactone. In the ROESY spectrum of compound $\mathbf{1 0}$ the rOe effect observed between the $\beta$-oriented protons $\mathrm{H}_{\mathrm{a}}-22 / \mathrm{H}-23$, and $\mathrm{H}-23 / \mathrm{H}-27$ indicated a 23,25 trans-configuration and suggested a $\beta$-oriented Me 27 (Figure 4). The ${ }^{3} \mathrm{C}$ NMR chemical shifts of C-27 $\left(\delta_{\mathrm{C}} 14.5\right)$ and carbons of the terminal $\gamma$-lactone were in accordance with the data of hovenidulciogenin $B$ (Yoshikawa et al., 1996). For compound 11, the rOe effect observed between the $\beta$-oriented protons $\mathrm{H}_{\mathrm{a}}-22 / \mathrm{H}-23$, and $\mathrm{H}-23 / \mathrm{H}-25$ suggested an $\alpha$-oriented methyl 27 (Figure 4). This was readily confirmed by the ${ }^{13} \mathrm{C}$ NMR chemical shifts of $\mathrm{C}-27\left(\delta_{\mathrm{C}} 13.7\right)$ and carbons of the terminal $\gamma$-lactone with the 25-epi hovenidulciogenin B (Yoshikawa et al., 1996). Thus, compound 10 is the new $(25 S) 3-O$ - $\alpha$-L-rhamnopyranosyl-( $1 \rightarrow 2)-\beta$-D-glucopyranosyloxy-20oxo-16,17-seco-21(20 $\rightarrow 17)$-abeodammarane-16,18:26,23-diolide and compound 11 is (25R) 3$O$ - $\alpha$-L-rhamnopyranosyl-( $1 \rightarrow 2)$ - $\beta$-D-glucopyranosyloxy-20-oxo-16,17-seco-21(20 $\rightarrow 17)$ abeodammarane-16,18:26,23-diolide.

The antioxidant activity of the EtOAc and hydromethanol extracts at $200 \mu \mathrm{g} / \mathrm{mL}$ was $9.6 \%$ and $53.4 \%$, respectively. The aqueous methanol extract was the most active with an $\mathrm{EC}_{50}=$ $180 \mu \mathrm{g} / \mathrm{mL}$ for the DPPH radical scavenging activity. This activity is low considering the presence of rutin (16), the major component in this extract, for which the DPPH radical scavenging activity has already been demonstrated with an $\mathrm{EC}_{50}=15.3 \mu \mathrm{g} / \mathrm{mL}$ (Lue et al., 2010).

The aqueous methanol extract showed $10 \%$ inhibition of tyrosinase. The four flavonoids (1619) were tested at $1 \mathrm{mg} / \mathrm{mL}$ and no activity was observed, probably due to the glycosylation at 
C-3, as observed previously with various flavonoids (Kubo and Kinst-Hori, 1999, Parvez et al., 2007).

The cytotoxic activity of the two norlupane triterpenoids $(\mathbf{1}, \mathbf{1 2})$, six dammarane saponins (4$\mathbf{6}, \mathbf{1 1}, \mathbf{1 3}, \mathbf{1 5})$ and the ceanothic acid saponin (2) against KB cell line, was measured using a WST-1 proliferation test. All tested saponins showed very low cytotoxic activity with growth inhibitions ranging from 6.6 to $22.9 \%$ at $10 \mu \mathrm{g} / \mathrm{mL}$ (Table 6). The two triterpenoids were the most active with $79.5 \%$ ( $\mathrm{IC}_{50}$ of $1.2 \pm 0.3 \mu \mathrm{g} / \mathrm{mL}$ ) and $58.4 \%$ ( $\mathrm{IC}_{50}$ near $10 \mu \mathrm{g} / \mathrm{mL}$ ) growth inhibition, respectively. The $\mathrm{IC}_{50}$ values of ceanothenic acid (12) showed good cytotoxic activity $(2.6 \mu \mathrm{M})$ and is approximatively ten times more active than its previously undescribed derivative 29-hydroxyceanothenic acid (1).

The disk diffusion method was used to evaluate the possible antimicrobial activity of the three lupane triterpenes $(\mathbf{1}, \mathbf{1 2}, \mathbf{2 0})$, six dammarane saponins (4-6, 13-15) and saponin 2 against four bacteria, including two Gram positive (S. aureus and E. faecalis) and two Gram negative (E. coli and $P$. aeruginosa). Only ceanothenic acid (12) and 29-hydroxyceanothenic acid (1) showed moderate antibacterial activity against $S$. aureus and E. faecalis with inhibition diameters of 14 and $16 \mathrm{~mm}$, respectively. Compounds 1 and 12 showed good antibacterial activity against $S$. aureus with MIC values of 4 and $8 \mu \mathrm{g} / \mathrm{mL}$, respectively and moderate antibacterial activity against $E$. faecalis (both $\mathrm{MIC}=16 \mu \mathrm{g} / \mathrm{mL}$ ) (Table 7).

In conclusion, twenty two compounds were isolated from the leaves of A. xerocarpus including thirteen triterpenoid saponins, two norlupane triterpenoids and four flavonoids. Ten saponins (2-11) are previously undescribed compounds, and the genins of saponins 6 and 9-11 are described for the first time. All the flavonoids (16-19) have been detected for the first time in Alphitonia species. Rutin (16) and kaempferol 3-O-rutinoside (17) are common flavonoids and were previously isolated for example from the fruit of Ziziphus jujuba and Z. spina-christi fruits (Pawlowska et al., 2008) or Ziziphus lotus leaves (Maciuk et al., 2003), members of the Rhamnaceae family. The two other kaempferol flavonoids (18-19) were isolated for the first time from the Rhamnaceae family. Rutin is the major compound of the aqueous methanol extract and A. xerocarpus can be considered has a new source of rutin. The aqueous methanol extract showed antioxidant activity (DPPH assay) due to the presence of flavonoids.

Ceanothenic acid (12), the major compound of the leaves, showed good cytotoxic activity against a $\mathrm{KB}$ cell line $\left(\mathrm{IC}_{50}=2.6 \mu \mathrm{M}\right)$ and antibacterial activity against $S$. aureus and $E$. faecalis with MIC values of 8 and $16 \mu \mathrm{g} / \mathrm{mL}$, respectively. The related 29hydroxyceanothenic acid (1) exhibited moderate cytotoxic activity $\left(\mathrm{IC}_{50}=10 \mu \mathrm{M}\right)$ and good 
antibacterial activity against $S$. aureus $(\mathrm{MIC}=4 \mu \mathrm{g} / \mathrm{mL})$ and moderate antibacterial activity against $E$. faecalis $(\mathrm{MIC}=16 \mu \mathrm{g} / \mathrm{mL})$.

\section{Experimental}

\subsection{General experimental procedures}

Optical rotations were determined in $\mathrm{MeOH}$ with a Perkin-Elmer 341 polarimeter. ${ }^{1} \mathrm{H}$ and ${ }^{13} \mathrm{C}$ NMR spectra were recorded on a Bruker Avance III 500 spectrometer $\left({ }^{1} \mathrm{H}\right.$ at $500 \mathrm{MHz}$ and ${ }^{13} \mathrm{C}$ at $125 \mathrm{MHz}$ ). 2D-NMR experiments were performed using standard Bruker microprograms. Chemical shifts $(\delta)$ are reported in ppm using the internal solvent resonances at $\delta_{\mathrm{H}} 3.33$ and $\delta_{\mathrm{C}} 47.6\left(\mathrm{CD}_{3} \mathrm{OD}\right)$. HR-ESI-MS experiments were performed using a hybrid quadrupole/time-of-flight (Q-TOF) instrument, equipped with a pneumatically assisted electrospray ion source operated in the positive ionization mode (Micromass, Manchester, UK). The samples were introduced by direct infusion in a solution of $\mathrm{MeOH}$ at a flow rate of $5 \mu \mathrm{L} / \mathrm{min}$. The spray capillary voltage was set at $3500 \mathrm{~V}$, and the extraction cone voltage between $30-60 \mathrm{~V}$. The source temperature was $80^{\circ} \mathrm{C}$ and the desolvatation temperature was $100^{\circ} \mathrm{C}$.

Preparative and analytical TLC was carried out on precoated silica gel $60 \mathrm{~F}_{254}$ plates (Merck, Darmstadt, Germany). Spots were visualized after spraying with $50 \% \mathrm{H}_{2} \mathrm{SO}_{4}$ and heating at $100{ }^{\circ} \mathrm{C}$ for $1 \mathrm{~min}$. CC was carried out on Kieselgel 60 (63-200 mesh), or LiChroprep RP-18 (40-63 $\mu \mathrm{m})$ Merck. Analytical and semi-preparative HPLC was performed on a Dionex apparatus equipped with an ASI-100 automated sample injector, a STH 585 column oven, a P580 pump, a diode array detector UVD 340S and the Chromeleon ${ }^{\circledR}$ software version 6.8. Analytical HPLC separations were performed on a prepacked $\mathrm{C}_{18}$ reversed phase column Luna (250 x $4.6 \mathrm{~mm}, 5 \mu \mathrm{m}$, Phenomenex, France). Semi-preparative HPLC separations were performed on a prepacked $\mathrm{C}_{18}$ reversed phase column Luna $(250 \mathrm{x} 10 \mathrm{~mm}, 5 \mu \mathrm{m}$, Phenomenex, France). The chromatograms were monitored at 205, 210, 254 and $312 \mathrm{~nm}$.

96-well microplates Greiner ${ }^{\circledR}$ F Bottom (BMG-LABTECH, Champigny sur Marne, France) and a BMG-LABTECH UV-Vis Spectrophotometer Micro-plate reader FLUOstar Omega were used for absorbance measurements in biological assays. DPPH, mushroom tyrosinase (EC 1.14.18.1), L-DOPA, kojic acid (purity 99\%), ascorbic acid, and $\alpha$-hederin were purchased from Sigma-Aldrich. WST-1 was obtained from Roche and DMEM F12 was purchased from Gibco-Invitrogen. The KB cell line DSMZ ACC136 was purchased from Interchim ${ }^{\circledR}$. Deionised water was used to prepare all aqueous solutions. 


\subsection{Plant material}

Alphitonia xerocarpus Baill. leaves were collected by Pr. Mohammed Nour in September 2009 at the end of the cool season in the ultramafic soil of Bois de Sud, located in southern province. The botanical identification was made at the Laboratoire Insulaire du Vivant et de l'Environnement of the New Caledonia University. A voucher specimen (09NM002) has been deposited in the Herbarium of Noumea (New Caledonia).

\subsection{Extraction and isolation}

Powdered air-dried leaves of A. xerocarpus $(150 \mathrm{~g})$ were macerated overnight in $2.5 \mathrm{~L}$ of petroleum ether and lixiviated to give $2.8 \mathrm{~g}$ of petroleum ether extract after evaporation. The defatted powdered material was then macerated overnight and lixiviated with $2.5 \mathrm{~L}$ of EtOAc to afford, after evaporation of the solvent, $3.5 \mathrm{~g}$ of EtOAc extract. After drying, the resulting powdered material was refluxed for $3 \mathrm{~h}$ with $\mathrm{MeOH}-\mathrm{H}_{2} \mathrm{O}$ (8:2) (2.5 L). Evaporation under reduced pressure afforded $52 \mathrm{~g}$ of a aqueous methanol extract.

The EtOAc extract ( $3.5 \mathrm{~g}$ ) was fractionated by silica gel column chromatography using a gradient of $\mathrm{CHCl}_{3}-\mathrm{MeOH}$ (from 1:0 to 6:4), to afford 200 fractions (200 mL each). Fractions [37-99] eluted with $\mathrm{CHCl}_{3}-\mathrm{MeOH}$ (99.5:0.5) contain compound 21 (2.8 mg). Fractions [5365] (133 mg), eluted with $\mathrm{CHCl}_{3}-\mathrm{MeOH}$ (98:2), were separated by silica gel column chromatography using a gradient of $\mathrm{CHCl}_{3}-\mathrm{MeOH}$ (from 1:0 to 9:1), to afford compound 20 (4 mg). Fractions [118-123] (380.8 mg), eluted with $\mathrm{CHCl}_{3}-\mathrm{MeOH}$ (85:15), were submitted to a silica gel column chromatography using a gradient of toluene: $\mathrm{MeOH}$ (from 1:0 to 7:3), and then the resulting fractions [91-103] were fractionated by RP-18 column chromatography, using a gradient of $\mathrm{MeOH}-\mathrm{H}_{2} \mathrm{O}$ (6:4 to 1:0), to give compound 22 (2.5 mg). Fractions [124126] (237.7 mg), eluted with $\mathrm{CHCl}_{3}-\mathrm{MeOH}(8: 2)$, were precipitated into the mixture $\mathrm{CHCl}_{3}-$ $\mathrm{MeOH}$ (97.5:2.5), to give compound 12 (207 mg). Fractions [151-163] (158.5 mg), eluted with $\mathrm{CHCl}_{3}-\mathrm{MeOH}(6: 4)$, were submitted to a silica gel column chromatography using a gradient of $\mathrm{CHCl}_{3}-\mathrm{MeOH}$ (from 99:1 to 9:1), and the resulting fractions were subjected to semi-prep HPLC on RP-18 eluting with $\mathrm{MeOH}-\mathrm{H}_{2} \mathrm{O}$ gradient system (81:19 to 86:14) during 15 min yielding compound 1 (Rt $9.58 \mathrm{~min} ; 7.5 \mathrm{mg}$ ).

A part of the aqueous methanol extract ( $19 \mathrm{~g}$ ) was subjected to vacuum liquid chromatography on RP-18, eluting successively with $1 \mathrm{~L}$ of $\mathrm{MeOH}-\mathrm{H}_{2} \mathrm{O}$ (4:6, 6:4, 8:2 and 1:0), to give fractions I (7.74 g), II, (5.9 g), III (3.6 g) and IV (880 mg), respectively. From Fraction I, compound 16 (640 mg) was obtained by precipitation during the process of 
methanol evaporation. Fraction II ( $5 \mathrm{~g}$ ) was fractionated by silica gel column chromatography using a gradient of $\mathrm{CHCl}_{3}-\mathrm{MeOH}-\mathrm{H}_{2} \mathrm{O}$ (from 1:0:0 to 60:40:7), to afford 128 fractions (200 mL each). Fractions [33-96] (133.6 mg), eluted with $\mathrm{CHCl}_{3}-\mathrm{MeOH}$ (8:2), were separated by silica gel column chromatography using a gradient of $\mathrm{CHCl}_{3}-\mathrm{MeOH}$ (9:1 to 8:2), to give compound $14(13.3 \mathrm{mg})$ in the fractions [90-103], eluted with $\mathrm{CHCl}_{3}-\mathrm{MeOH}(8: 2)$. The resulting fractions [44-52], eluted with $\mathrm{CHCl}_{3}-\mathrm{MeOH}$ (85:15), were subjected to semi-prep HPLC on RP-18 eluting with the isocratic mixture $\mathrm{CH}_{3} \mathrm{CN}-\mathrm{H}_{2} \mathrm{O} 0.025 \%$ TFA (35:65) during $20 \mathrm{~min}$ yielding compounds 9 (Rt $15.4 \mathrm{~min} ; 2.3 \mathrm{mg}), \mathbf{1 0}(R \mathrm{t} 16.6 \mathrm{~min} ; 5.0 \mathrm{mg})$, and $11(R \mathrm{t}$ $17.5 \mathrm{~min} ; 11.0 \mathrm{mg}$ ). Fractions [40-45] (284.1 mg), eluted with $\mathrm{CHCl}_{3}-\mathrm{MeOH}(8: 2)$, were fractionated by silica gel column chromatography using a gradient of toluene- $\mathrm{MeOH}(9: 1$ to 7:3). Fractions [40-54], eluted with toluene-MeOH (85:15), were subjected to semi-prep HPLC on RP-18 eluted with an isocratic mixture of $\mathrm{CH}_{3} \mathrm{CN}-\mathrm{H}_{2} \mathrm{O}$ 0.025\% TFA (25:75) during $25 \mathrm{~min}$ to afford compounds 17 (Rt $11.1 \mathrm{~min} ; 8.5 \mathrm{mg}), \mathbf{1 8}(R \mathrm{t} 12.9 \mathrm{~min} ; 10.5 \mathrm{mg})$, and 19 (Rt $13.1 \mathrm{~min} ; 3.6 \mathrm{mg})$. Fractions [55-64], eluted with toluene-MeOH (8:2), were further submitted to a silica gel preparative TLC using $\mathrm{CHCl}_{3}-\mathrm{MeOH}-\mathrm{H}_{2} \mathrm{O}$ (70:30:5) as eluent to give $14 \mathrm{mg}$ of compound 7. Fractions [88-97] (225.6 mg), eluted with $\mathrm{CHCl}_{3}-\mathrm{MeOH}-\mathrm{H}_{2} \mathrm{O}$ (70:30:5), was fractionated by RP-18 column chromatography using a gradient of $\mathrm{MeOH}-\mathrm{H}_{2} \mathrm{O}$ (from 3:7 to 7:3) to give compound $\mathbf{1 4}(7.6 \mathrm{mg})$ in the fractions [71-73]. The resulting fractions [74-79] (18.5 mg), eluted with $\mathrm{MeOH}-\mathrm{H}_{2} \mathrm{O}$ (4:6), were separated by silica gel preparative TLC using $\mathrm{CHCl}_{3}-\mathrm{MeOH}-\mathrm{H}_{2} \mathrm{O}$ (70:30:5) as eluent to give compound 15 (9 mg). Fractions [115-116] (188.3 mg), eluted with $\mathrm{CHCl}_{3}-\mathrm{MeOH}-\mathrm{H}_{2} \mathrm{O}$ (70:30:5), were fractionated by silica gel column chromatography using a gradient of toluene:MeOH $(85: 15$ to $6: 4, \mathrm{v} / \mathrm{v})$. The resulting fractions [43-81], eluted with toluene-MeOH (75:25), were subjected to semi-prep HPLC on RP-18 eluting with a gradient of $\mathrm{CH}_{3} \mathrm{CN}-\mathrm{H}_{2} \mathrm{O} 0.025 \%$ TFA (2:8 to $35: 65$ ) during 15 min to yield compounds 16 (Rt $8.2 \mathrm{~min} ; 2.1 \mathrm{mg}$ ), and 14 (Rt $16.9 \mathrm{~min} ; 3.8 \mathrm{mg}$ ). Fractions [123-125] (358.7 mg), eluted with $\mathrm{CHCl}_{3}-\mathrm{MeOH}-\mathrm{H}_{2} \mathrm{O}$ (60:40:7), were fractionated by RP-18 column chromatography using a gradient of $\mathrm{MeOH}-\mathrm{H}_{2} \mathrm{O}$ (from 3:7 to 6:4). Fractions [55-67], eluted with $\mathrm{MeOH}-\mathrm{H}_{2} \mathrm{O}$ (45:55), were subjected to semi-prep HPLC on RP-18 eluting with an isocratic mixture of $\mathrm{CH}_{3} \mathrm{CN}-\mathrm{H}_{2} \mathrm{O} 0.025 \%$ TFA (22:88) during 25 min to give compound 2 ( $R \mathrm{t}$ $19.8 \mathrm{~min} ; 13.1 \mathrm{mg}$ ). Fraction III ( $3 \mathrm{~g}$ ) was fractionated by silica gel column chromatography using a gradient of $\mathrm{CHCl}_{3}-\mathrm{MeOH}-\mathrm{H}_{2} \mathrm{O}$ (from 1:0:0 to 70:30:5), to afford 82 fractions (135 mL each). Fraction [32] (139.6 mg), eluted with $\mathrm{CHCl}_{3}-\mathrm{MeOH}(8: 2)$, was submitted to a RP-18 column chromatography, using a gradient of $\mathrm{MeOH}-\mathrm{H}_{2} \mathrm{O}$ (3:7 to 7:3), to give compound 13 (3.5 mg). The resulting fractions [161-182] (25.1 mg), eluted with $\mathrm{MeOH}-\mathrm{H}_{2} \mathrm{O}$ (55:45), were 
subjected to semi-prep HPLC on RP-18 eluted with a gradient of $\mathrm{CH}_{3} \mathrm{CN}-\mathrm{H}_{2} \mathrm{O} 0.025 \%$ TFA (39:61 to 4:6) during 15 min yielding compounds 8 (Rt $6.7 \mathrm{~min} ; 2.1 \mathrm{mg}$ ), and 7 (Rt $8.7 \mathrm{~min}$; $5.5 \mathrm{mg}$ ). Fractions [33-34] (178.6 mg), eluted with $\mathrm{CHCl}_{3}-\mathrm{MeOH}(8: 2)$, were fractionated by RP-18 column chromatography using a gradient of $\mathrm{MeOH}-\mathrm{H}_{2} \mathrm{O}$ (4:6 to 8:2), to give compound 13 (4.0 mg) eluted with $\mathrm{CHCl}_{3}-\mathrm{MeOH}$ (45:55). The resulting fractions [59-63], eluted with $\mathrm{MeOH}-\mathrm{H}_{2} \mathrm{O}$ (6:4), were subjected to semi-prep HPLC on RP-18 eluting with an isocratic mixture of $\mathrm{CH}_{3} \mathrm{CN}-\mathrm{H}_{2} \mathrm{O} 0.025 \%$ TFA (39:61) during 15 min to afford compounds 8 (Rt $8.5 \mathrm{~min} ; 4.0 \mathrm{mg}$ ), and 3 (Rt $11.5 \mathrm{~min} ; 2.5 \mathrm{mg}$ ). Fractions [35-39] (346.1 mg), eluted with $\mathrm{CHCl}_{3}-\mathrm{MeOH}(8: 2)$, were submitted to a silica gel column chromatography using a gradient of $\mathrm{CHCl}_{3}-\mathrm{MeOH}-\mathrm{H}_{2} \mathrm{O}$ (from 1:0:0 to 70:30:5). The resulting fractions [47-54] (40.5 mg), eluted with $\mathrm{CHCl}_{3}-\mathrm{MeOH}$ (8:2), were separated by semi-prep HPLC on RP-18 eluting with a gradient of $\mathrm{CH}_{3} \mathrm{CN}-\mathrm{H}_{2} \mathrm{O}$ 0.025\% TFA (35:65 to 45:55) during 15 min to give compound 14 (Rt $14.2 \mathrm{~min} ; 2.7 \mathrm{mg}$ ). Fractions [40-48] (260.1 mg), eluted with $\mathrm{CHCl}_{3}-\mathrm{MeOH}(8: 2)$, were fractionated by RP-18 column chromatography, using a gradient of $\mathrm{MeOH}-\mathrm{H}_{2} \mathrm{O}$ (4:6 to 7:3), to give compound 13 (98.6 mg) eluted with $\mathrm{CHCl}_{3}-\mathrm{MeOH}$ (45:55). Fractions [110-125], eluted with $\mathrm{MeOH}-\mathrm{H}_{2} \mathrm{O}$ (5:5), were separated by silica gel column chromatography using a gradient of $\mathrm{CHCl}_{3}-\mathrm{MeOH}$ (9:1 to 85:15) to give $3.1 \mathrm{mg}$ of compound 6. Fractions [137-143], eluted with $\mathrm{MeOH}-\mathrm{H}_{2} \mathrm{O}(6: 4)$, were fractionated by silica gel column chromatography using a gradient of $\mathrm{CHCl}_{3}-\mathrm{MeOH}(1: 0$ to 7:3) and the resulting fractions [90-137], eluted with $\mathrm{CHCl}_{3}: \mathrm{MeOH}$ (85:15), were finally submitted to a silica gel prep TLC using $\mathrm{CHCl}_{3}-\mathrm{MeOH}-$ $\mathrm{H}_{2} \mathrm{O} 1 \%$ TFA (75:25:3) as eluent to afford $7.7 \mathrm{mg}$ of compound 14. Fractions [56-59] (272.9 mg), eluted with $\mathrm{CHCl}_{3}-\mathrm{MeOH}$ (7:3), were fractionated by RP-18 column chromatography, using a gradient of $\mathrm{MeOH}-\mathrm{H}_{2} \mathrm{O}$ (3:7 to 9:1). Fractions [62-108] (37.8 mg), eluted with $\mathrm{MeOH}-\mathrm{H}_{2} \mathrm{O}$ (3:7), were then submitted to a silicagel prep TLC using $\mathrm{CHCl}_{3}-\mathrm{MeOH}-\mathrm{H}_{2} \mathrm{O} 1 \%$ TFA (75:25:3) as eluent to afford compounds $14(12.0 \mathrm{mg})$ and $\mathbf{1 5}(10.0 \mathrm{mg})$. Fractions [142156] (33.4 mg), eluted with $\mathrm{CHCl}_{3}-\mathrm{MeOH}$ (5:5), were fractionated by silica gel column chromatography using a gradient of $\mathrm{CHCl}_{3}: \mathrm{MeOH}(1: 0$ to $70: 30, \mathrm{v} / \mathrm{v})$ to give compound 13 (16.0 mg). Fractions [171-174] (35 mg), eluted with $\mathrm{MeOH}-\mathrm{H}_{2} \mathrm{O}(8: 2)$, contained a mixture of compounds 4 and 5 (6 mg), inseparable by silica gel column chromatography.

\subsection{Compound characterization}

\subsubsection{9-hydroxyceanothenic acid (1)}

White amorphous powder; $[\alpha]_{\mathrm{D}}+3.2^{\circ}\left(c 0.16, \mathrm{CHCl}_{3}\right) ;{ }^{1} \mathrm{H} \mathrm{NMR}\left(\mathrm{CDCl}_{3}, 500 \mathrm{MHz}\right) \delta: 0.94(s$, H-24), 1.01 ( $s, \mathrm{H}-23), 1.01$ ( $s, \mathrm{H}-25), 1.08$ ( $s, \mathrm{H}-26), 1.26$ ( $d d, 11.2-3.6, \mathrm{H}-5), 1.39$ (dd, 12.8 - 
2.9, H-16a), 1.44 ( $m$, H-21a, H-22a), 1.45 ( $m$, H-6a), 1.46 (dd, 15.3-3.9, H-15a), 1.49 (m, H6b) 1.50 (m, H-11a), 1.55 ( $d d, 12.8-4.5, \mathrm{H}-12 \mathrm{a}), 1.60$ ( $d d, 12.8-4.9, \mathrm{H}-11 \mathrm{~b}), 1.64$ (brd, 13.4, H-7a), 1.77 ( $d d, 12.6-5.6, \mathrm{H}-7 \mathrm{~b}), 1.83$ ( $t, 11.3, \mathrm{H}-18), 1.89$ ( $d d, 12.5-2.9, \mathrm{H}-9), 1.94$ ( $d d$, 10.78.3, H-22b), 2.06 (dt, 13.5-2.4, H-15b), 2.06 ( $m, \mathrm{H}-21 \mathrm{~b}), 2.23$ (dd, 12.8-5.5, H-12b), 2.37 (dt, 12.8-3.2, H-16b), 2.42 ( $t d, 12.5-5.3, \mathrm{H}-13$ ), 3.03 ( $t d, 12.5-4.0, \mathrm{H}-19), 4.05$ (d, 14.8, H-30a), 4.16 (d, 14.8, H-30b), 4,95 (brs, H-29a), 4,99 (d, 1.5, H-29b), 5.43 (d, 5.7, H-3), 5.96 (d, 5.7, $\mathrm{H}-2) ;{ }^{13} \mathrm{C} \mathrm{NMR}\left(\mathrm{CDCl}_{3}, 125 \mathrm{MHz}\right) \delta: 18.5$ (C-6), 18.7 (C-26), 20.7 (C-25), 21.8 (C-24), 24.2 (C-11), 27.7 (C-12), 29.1 (C-15), 29.7 (C-23), 33.1 (C-21), 35.4 (C-16), 37.9 (C-22), 38.9 (C7), 40.8 (C-13), 42.4 (C-8), 44.6 (C-19), 45.7 (C-4), 49.5 (C-9), 51.8 (C-10), 52.8 (C-18), 57.2 (C-17), 61.1 (C-14), 63.8 (C-5), 64.9 (C-29), 107.7 (C-30), 140.1 (C-3), 141.7 (C-2), 155.5 (C-20), 178.6 (C-27), 179.3 (C-28); HRESIMS (positive-ion mode) $\mathrm{m} / z: 493.2936[\mathrm{M}+\mathrm{Na}]^{+}$ (calcd for $\mathrm{C}_{29} \mathrm{H}_{42} \mathrm{O}_{57} \mathrm{Na}, 493.2930$ ).

3.4. 2. 28-O- $\beta$-D-glucopyranosyl- $(1 \rightarrow 6)$-[ $\beta$-D-glucopyranosyl- $(1 \rightarrow 3)]$-[ $\beta$-D-glucopyranosyl$(1 \rightarrow 2)]-\beta$-D-glucopyranosyl- $(1 \rightarrow 2)-\beta$-D-glucopyranosylceanothic acid (2)

White amorphous powder; $[\alpha]_{\mathrm{D}}-26.4^{\circ}\left(c \mathrm{0.17}, \mathrm{CH}_{3} \mathrm{OH}\right) ;{ }^{1} \mathrm{H}$ NMR (MeOD-d4, $\left.500 \mathrm{MHz}\right)$ and ${ }^{13} \mathrm{C}$ NMR (MeOD-d4, $125 \mathrm{MHz}$ ), see Table 1; HRESIMS (positive-ion mode) $\mathrm{m} / \mathrm{z}$ : 1319.5892 [M+Na] ${ }^{+}$(calcd for : $\mathrm{C}_{60} \mathrm{H}_{96} \mathrm{O}_{30} \mathrm{Na}, 1319.5884$ ).

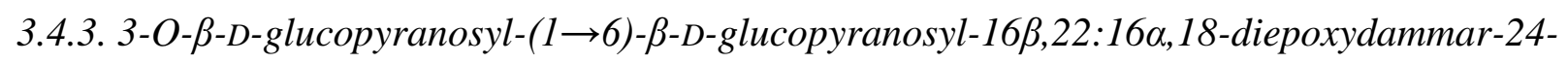

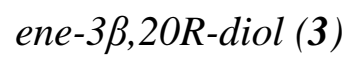

White amorphous powder; $[\alpha]_{\mathrm{D}}-8.3^{\circ}\left(c\right.$ 0.12, $\left.\mathrm{CH}_{3} \mathrm{OH}\right) ;{ }^{1} \mathrm{H}$ NMR $(\mathrm{MeOD}-\mathrm{d} 4,500 \mathrm{MHz})$ and ${ }^{13} \mathrm{C}$ NMR (MeOD-d4, $125 \mathrm{MHz}$ ), see Tables 1 and 2; HRESIMS (positive-ion mode) $\mathrm{m} / \mathrm{z}$ : 819.4529 [M+Na] ${ }^{+}\left(\right.$calcd for $\left.\mathrm{C}_{42} \mathrm{H}_{68} \mathrm{O}_{14} \mathrm{Na}, 819.4507\right)$.

3.4.5. 3-O- $\beta$-D-xylopyranosyl-( $(1 \rightarrow 6)$ - $\beta$-D-glucopyranosyl- $(1 \rightarrow 2)$ - $\beta$-D-glucopyranosyl- $(1 \rightarrow 3)$ [ $\alpha$-L-rhamnopyranosyl- $(1 \rightarrow 2)]$ - $\alpha$-L-arabinopyranosyljujubogenin (4) White amorphous powder; ${ }^{1} \mathrm{H}$ NMR (MeOD-d4, $500 \mathrm{MHz}$ ) and ${ }^{13} \mathrm{C}$ NMR (MeOD-d4, 125 $\mathrm{MHz}$ ), see Tables 2 and 3; HRESIMS (positive-ion mode) $\mathrm{m} / z: 1229.5923[\mathrm{M}+\mathrm{Na}]^{+}$(calcd for $\left.\mathrm{C}_{58} \mathrm{H}_{94} \mathrm{O}_{26} \mathrm{Na}, 1229.5931\right)$.

3.4.6. 3-O- $\alpha$-L-arabinopyranosyl-( $1 \rightarrow 6)$ - $\beta$-D-glucopyranosyl-( $(\rightarrow 2)-\beta$-D-glucopyranosyl$(1 \rightarrow 3)$-[ $\alpha$-L-rhamnopyranosyl- $(1 \rightarrow 2)]-\alpha$-L-arabinopyranosyljujubogenin $(5)$ 
White amorphous powder; ${ }^{1} \mathrm{H}$ NMR (MeOD-d4, $500 \mathrm{MHz}$ ) and ${ }^{13} \mathrm{C}$ NMR (MeOD-d4, 125 $\mathrm{MHz}$ ) of the aglycone part is identical to compound $4 \pm 0.2 \mathrm{ppm} ;{ }^{1} \mathrm{H}$ NMR (MeOD-d4, 500 $\mathrm{MHz}$ ) and ${ }^{13} \mathrm{C}$ NMR (MeOD-d4, $125 \mathrm{MHz}$ ) of the osidic part, see Table 3; HRESIMS (positive-ion mode) $\mathrm{m} / \mathrm{z}: 1229.5923[\mathrm{M}+\mathrm{Na}]^{+}\left(\right.$calcd for $\left.\mathrm{C}_{58} \mathrm{H}_{94} \mathrm{O}_{26} \mathrm{Na}, 1229.5931\right)$.

\subsubsection{3-O- $\beta$-D-glucopyranosyl-( $1 \rightarrow 6)-\beta$-D-glucopyranosyl-22 $\alpha$-hydroxyjujubogenin (6)}

White amorphous powder; $[\alpha]_{\mathrm{D}}-27.8^{\circ}\left(c\right.$ 0.18, $\left.\mathrm{CH}_{3} \mathrm{OH}\right) ;{ }^{1} \mathrm{H} \mathrm{NMR}(\mathrm{MeOD}-\mathrm{d} 4,500 \mathrm{MHz})$ and ${ }^{13} \mathrm{C}$ NMR (MeOD-d4, $125 \mathrm{MHz}$ ), see Tables 2 and 4; HRESIMS (positive-ion mode) $\mathrm{m} / \mathrm{z}$ : $835.4463[\mathrm{M}+\mathrm{Na}]^{+}\left(\right.$calcd for $\left.\mathrm{C}_{42} \mathrm{H}_{68} \mathrm{O}_{15} \mathrm{Na}, 835.4456\right)$.

3.4.8. 3-O-[6-O-(trans, cis)-p-coumaroyl- $\beta$-D-glucopyranosyl- $(1 \rightarrow 6)]-\beta$-D-glucopyranosyl-22 $\alpha$ hydroxyjujubogenin (7)

White amorphous powder; $[\alpha]_{\mathrm{D}}-15.8^{\circ}\left(c \mathrm{0.18}, \mathrm{CH}_{3} \mathrm{OH}\right) ;{ }^{1} \mathrm{H}$ NMR $(\mathrm{MeOD}-\mathrm{d} 4,500 \mathrm{MHz})$ and ${ }^{13} \mathrm{C}$ NMR (MeOD-d4, $125 \mathrm{MHz}$ ) of the aglycone part is identical to compound $6 \pm 0.2 \mathrm{ppm}$; ${ }^{1} \mathrm{H}$ NMR (MeOD-d4, $500 \mathrm{MHz}$ ) and ${ }^{13} \mathrm{C}$ NMR (MeOD-d4, $125 \mathrm{MHz}$ ) of the osidic part, see Table 4; HRESIMS (positive-ion mode) $m / z: 981.4822[\mathrm{M}+\mathrm{Na}]^{+}$(calcd for $\mathrm{C}_{51} \mathrm{H}_{74} \mathrm{O}_{17} \mathrm{Na}$, 981.4824).

3.4.9. 3-O-[6-O-(trans, cis)-sinapoyl- $\beta$-D-glucopyranosyl-( $1 \rightarrow 6)]-\beta$-D-glucopyranosyl-22 $\alpha$ hydroxyjujubogenin $(\boldsymbol{8})$

White amorphous powder; $[\alpha]_{\mathrm{D}}-22.9^{\circ}\left(c \mathrm{0.28}, \mathrm{CH}_{3} \mathrm{OH}\right) ;{ }^{1} \mathrm{H}$ NMR $(\mathrm{MeOD}-\mathrm{d} 4,500 \mathrm{MHz})$ and ${ }^{13} \mathrm{C}$ NMR (MeOD-d4, $125 \mathrm{MHz}$ ) of the aglycone part is identical to compound $6 \pm 0.2 \mathrm{ppm}$; ${ }^{1} \mathrm{H}$ NMR (MeOD-d4, $500 \mathrm{MHz}$ ) and ${ }^{13} \mathrm{C}$ NMR (MeOD-d4, $125 \mathrm{MHz}$ ) of the osidic part, see Table 4; HRESIMS (positive-ion mode) $\mathrm{m} / z$ : $1041.5024[\mathrm{M}+\mathrm{Na}]^{+}\left(\right.$calcd for $\mathrm{C}_{53} \mathrm{H}_{78} \mathrm{O}_{19} \mathrm{Na}$, 1041.5035).

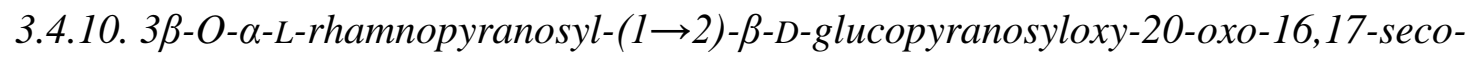
21(20 $\rightarrow$ 17)-abeodammar-24-ene-16,18:26,23-diolide (9)

White amorphous powder; $[\alpha]_{\mathrm{D}}-14.1^{\circ}\left(c \mathrm{0.14}, \mathrm{CH}_{3} \mathrm{OH}\right) ;{ }^{1} \mathrm{H}$ NMR (MeOD-d4, $\left.500 \mathrm{MHz}\right)$ and ${ }^{13} \mathrm{C}$ NMR (MeOD-d4, $125 \mathrm{MHz}$ ), see Table 5; HRESIMS (positive-ion mode) $\mathrm{m} / \mathrm{z}: 831.4138$ $[\mathrm{M}+\mathrm{Na}]^{+}\left(\right.$calcd for $\mathrm{C}_{42} \mathrm{H}_{64} \mathrm{O}_{15} \mathrm{Na}, 831.4143$ ). 
3.4.11. (25S) 3-O- $\alpha$-L-rhamnopyranosyl- $(1 \rightarrow 2)-\beta$-D-glucopyranosyloxy-20-oxo-16,17-seco$21(20 \rightarrow 17)$-abeodammarane-16,18:26,23-diolide (10)

White amorphous powder; $[\alpha]_{\mathrm{D}}-46.6^{\circ}\left(c\right.$ 0.42, $\left.\mathrm{CH}_{3} \mathrm{OH}\right) ;{ }^{1} \mathrm{H}$ NMR (MeOD-d4, $\left.500 \mathrm{MHz}\right)$ and ${ }^{13} \mathrm{C}$ NMR (MeOD-d4, $125 \mathrm{MHz}$ ), see Table 5; HRESIMS (positive-ion mode) $\mathrm{m} / \mathrm{z}: 833.4286$ $[\mathrm{M}+\mathrm{Na}]^{+}\left(\right.$calcd for $\left.\mathrm{C}_{42} \mathrm{H}_{66} \mathrm{O}_{15} \mathrm{Na}, 833.4299\right)$.

3.4.12. (25R) 3-O- $\alpha$-L-rhamnopyranosyl-(1 $\rightarrow 2)-\beta$-D-glucopyranosyloxy-20-oxo-16,17-seco21(20 $\rightarrow 17)$-abeodammarane-16,18:26,23-diolide (11)

White amorphous powder; $[\alpha]_{\mathrm{D}}-38.9^{\circ}\left(c\right.$ 0.38, $\left.\mathrm{CH}_{3} \mathrm{OH}\right) ;{ }^{1} \mathrm{H}$ NMR (MeOD-d4, $\left.500 \mathrm{MHz}\right)$ and ${ }^{13} \mathrm{C}$ NMR (MeOD-d4, $125 \mathrm{MHz}$ ), see Table 5; HRESIMS (positive-ion mode) $\mathrm{m} / \mathrm{z}: 833.4286$ $[\mathrm{M}+\mathrm{Na}]^{+}$(calcd for $\mathrm{C}_{42} \mathrm{H}_{66} \mathrm{O}_{15} \mathrm{Na}, 833.4299$ ).

\subsection{Sugar analysis and determination of absolute configuration}

$1 \mathrm{~g}$ of the crude aqueous methanol extract was refluxed with $25 \mathrm{~mL}$ of TFA (2M) for $4 \mathrm{~h}$. After extraction with EtOAc $(3 \times 25 \mathrm{~mL})$, the aqueous layer was neutralized to $\mathrm{pH} 6$ with 50 $\mathrm{mM} \mathrm{KOH}$ and freeze-dried to provide the monosaccharide residue. The sugar profile was determined by TLC as previously described (Muhammad et al., 2015). The monosaccharide residue ( $40 \mathrm{mg}$ ) was solubilized in $\mathrm{H}_{2} \mathrm{O}(1 \mathrm{~mL})$ and purified by semi-preparative HPLC, on a specific column ROA $\left(250 \times 15 \mathrm{~mm}, \mathrm{~T}=35^{\circ} \mathrm{C}\right)$ eluted isocratically with a solution of $\mathrm{H}_{2} \mathrm{O}$ $0.25 \mu \mathrm{M} \mathrm{H}_{2} \mathrm{SO}_{4}$ at a flow rate of $3.5 \mathrm{~mL} / \mathrm{min}$, to give the four sugars. The chromatogram was monitored by a refractive index detector RI-410 $\left(\mathrm{T}=35^{\circ} \mathrm{C}\right)$. Each fraction was neutralized with a $50 \mathrm{mM}$ solution of $\mathrm{KOH}$, dried, dissolved in $1 \mathrm{~mL}$ pyridine, and filtered to remove potassium sulfate salts. After pyridine evaporation, the sugars were dissolved (0.1-0.5 $\mathrm{mg} / \mathrm{mL})$ in a mixture $n$-hexane-EtOH-TFA (70:30:1) and analyzed by HPLC on an analytical chiral column Chiralpak $^{\circledR}$ ICA, using the mobile phase $n$-hexane-EtOH-TFA (80:20:0.1) isocratically at a flow rate of $0.5 \mathrm{~mL} / \mathrm{min}$. Chromatograms were monitored by a refractive index detector RI-410 and identification of the sugars was carried out by comparing the retention times of standard D or L monosaccharide samples (Gossan et al., 2016; Lavaud et al., 2015, Lopes and Gaspar, 2008). Four sugars were identified as L-rhamnose $(\alpha \& \beta)$ at $R \mathrm{t}$ $11.7 \mathrm{~min}, \mathrm{~L}-$ arabinose $(\alpha \& \beta)$ at $R \mathrm{t}$ 14.6-15.5 min, D-xylose $(\alpha \& \beta)$ at $R \mathrm{t} 16.6-18.5$ and Dglucose $(\alpha \& \beta)$ at $R \mathrm{t}$ 18.3-23.2 $\mathrm{min}$.

\subsection{DPPH radical scavenging assay}


The radical scavenging activity of the EtOAc and aqueous methanol extracts of A. xerocarpus leaves was determined using the stable 1,1-diphenyl-2-picrylhydrazyl (DPPH) free radical (Muhammad et al., 2015). Briefly, a stock solution of DPPH was prepared at $158 \mu \mathrm{M}$ in $\mathrm{EtOH} / \mathrm{H}_{2} \mathrm{O}(1: 1, \mathrm{v} / \mathrm{v})$. Each sample was dissolved in DMSO $(200 \mu \mathrm{g} / \mathrm{mL})$ and $5 \mu \mathrm{L}$ were added to the DPPH stock solution $(95 \mu \mathrm{L})$, in triplicate in 96-well plates. The $\mathrm{DPPH}^{*}$ absorbance in each reaction mixture was monitored at $\lambda=515 \mathrm{~nm}$. Absorbance measurements were performed at regular interval of $1.5 \mathrm{~min}$ for $30 \mathrm{~min}$ at $37^{\circ} \mathrm{C}$ for all samples. The aqueous methanol extract was then tested at $200,100,50$ and $10 \mu \mathrm{g} / \mathrm{mL}$ to calculate the concentration able to quench $50 \%$ of the reaction system $\left(\mathrm{EC}_{50}\right)$ at $30 \mathrm{~min}$. The $\mathrm{EtOH} / \mathrm{H}_{2} \mathrm{O}(1: 1, \mathrm{v} / \mathrm{v})$ solution was used as a blank, the free DPPH solution was used as a negative control and ascorbic acid $(5 \mu \mathrm{g} / \mathrm{mL})$ was used as a positive control. Results are expressed as percentage decrease with respect to control values.

\subsection{Tyrosinase inhibitory activity assay}

The tyrosinase inhibitory activity of the EtOAc and aqueous methanol extracts of $A$. xerocarpus leaves and the four flavonoids (16-19) was determined against mushroom tyrosinase. The assay was performed according to a previously described method using LDOPA as substrate (Muhammad et al., 2015). Briefly, the tested compounds were dissolved in DMSO $10 \%$ and mixed (1:1) with Na-phosphate buffer (PBS, pH 6.8) to obtain a concentration of $4 \mathrm{mg} / \mathrm{mL}$ for the extracts or $1 \mathrm{mg} / \mathrm{mL}$ for the compounds. Tyrosinase (100 $\mu \mathrm{L} ; 135 \mathrm{U} / \mathrm{mL})$ was first pre-incubated with the tested compounds $(100 \mu \mathrm{L})$ at $25{ }^{\circ} \mathrm{C}$ for 10 min, and then $100 \mu \mathrm{L}$ of L-DOPA (0.5 mM, PBS pH 6.8) was added. The enzyme reaction was monitored by measuring the change in absorbance at $\lambda 475 \mathrm{~nm}\left(\right.$ at $\left.25^{\circ} \mathrm{C}\right)$ after $10 \mathrm{~min}$ incubation. These solutions were prepared in triplicate in 96-well plates. Kojic acid (1 mM) was used as positive control. The inhibitory percentage of tyrosinase was calculated as follows: \% inhibition $=\{[(A-B)-(C-D)] /(A-B)\} \times 100(A$ : OD at $475 \mathrm{~nm}$ without test substance; $B$ : OD at $475 \mathrm{~nm}$ without test substance and tyrosinase; $C$ : OD at $475 \mathrm{~nm}$ with test substance; $D$ : OD at $475 \mathrm{~nm}$ with test substance, but without tyrosinase).

\subsection{WST cytotoxicity assay}

The cytotoxic activities of compounds 1-2, 4-6, 11-13, and 15 on KB cell lines (ATTC ${ }^{\circledR}$ $\mathrm{CCL}^{\mathrm{TM}}$-17) were determined by using a colorimetry method based on the cleavage of the WST-1 tetrazolium salt (Muhammad et al., 2015), and using DMEM F12 medium for cells 
culture (Chwalek et al., 2006). The stock solutions of compounds $(1 \mathrm{mg} / \mathrm{mL})$ were prepared in DMSO. Sample dilutions were then performed in medium DMEM F12 $(1,2.5,5,7.5$ or $10 \mu \mathrm{g} / \mathrm{mL}$ ). After removal of pre-incubated culture medium, $200 \mu \mathrm{L}$ of DMEM F12 containing various concentrations of samples were added and further incubated for $48 \mathrm{~h}$ at 37 ${ }^{\circ} \mathrm{C}$. Cell viability was determined by adding WST-1 tetrazolium salt and by measuring the absorbance at $\lambda 450 \mathrm{~nm}$ after $\approx 1 \mathrm{~h}$. Each assay was realized in triplicate in 96 -well microplates. A dose-response curve was plotted for each compound, and the concentration giving 50\% inhibition ( $\mathrm{IC}_{50}$ ) was calculated by using MSExcel based program. $\alpha$-hederin was employed as a positive control, which exhibited an $\mathrm{IC}_{50}$ value of $5.5 \mu \mathrm{M}$ under the above conditions (Chwalek et al., 2006).

\subsection{Disc diffusion antibacterial assay}

Disk diffusion was used to screen antibacterial activity of compounds 1-2, 4-6, 12-15, and 20 against S. aureus (ATCC 25923) and E. faecalis (CIP10907), for Gram positive, E.coli (ATCC 25922) and P. aeruginosa (ATCC 27853), for gram negative (Acebey-Castellon et al., 2011). $50 \mu \mathrm{L}$ (of the solution at $10 \mathrm{mg} / \mathrm{mL}$ in $\mathrm{H}_{2} \mathrm{O}$ ) were applied in a sterile atmosphere to $8 \mathrm{~mm}$ diameter paper disks corresponding to $500 \mu \mathrm{g} / \mathrm{disk}$ of each compounds (or $100 \mu \mathrm{g} / \mathrm{disk}$ for 14). After evaporation of the solvent, paper disks were placed in Petri dished of $9 \mathrm{~cm}$ diameter containing nutrient Mueller-Hinton agar previously inoculated with $0.2 \mathrm{~mL}$ of suspension of bacteria ( $1510^{7} \mathrm{CFU} / \mathrm{mL}$ for $S$ aureus and $E$. faecalis; $1510^{6}$ for $E$ coli and $P$. aeruginosa). After 18 hours of incubation at $37^{\circ} \mathrm{C}$, the inhibition zone for the active extract was measured (CLSI, 2005). The antimicrobial gentamicine was used as positive control and tested at $50 \mu \mathrm{g} / \mathrm{disk}$.

\subsection{Broth diffusion antibacterial assay}

The liquid microdilution growth inhibition method (Acebey-Castellon et al., 2011, YaoKouassi et al., 2008) was used to determine the MIC values of the active compounds $\mathbf{1}$ and $\mathbf{1 2}$ against two standard strains $S$. aureus and E. faecalis. Briefly, the mother compound solutions $(10 \mathrm{mg} / \mathrm{mL})$ were prepared by dissolving the compound in DMSO. Fifty microliters of each solution was added to $950 \mu \mathrm{L}$ of Muller-Hinton medium. This was serially diluted 2-fold with Muller-Hinton medium to obtain concentration ranges of 4 to $256 \mu \mathrm{g} / \mathrm{mL}$. Fifty microliters of each concentration was added in a well (96-well microplate) containing $150 \mu \mathrm{L}$ of MuellerHinton medium and $5 \mu \mathrm{L}$ of the standard inoculum. The final concentration of DMSO in the 
well was less than 5\% (preliminary analysis with 5\% (v/v) DMSO/Mueller-Hinton medium affected neither the growth of the test organisms nor the change of color due to this growth). The negative control well consisted of $12.5 \mu \mathrm{L}$ of DMSO, 187.5 $\mu \mathrm{L}$ of Mueller-Hinton medium, and $5 \mu \mathrm{L}$ of the standard inoculum. The plates were covered with a sterile plate sealer, then agitated and incubated at $37{ }^{\circ} \mathrm{C}$ for $18 \mathrm{~h}$. Microbial growth was determined by observing the change of color in the wells. The lowest concentration showing no color change was considered as the MIC. The experiments were run in triplicate, and each time the MIC values were identical. Gentamicin $(25,12.5,5,2.5 \mu \mathrm{g} / \mathrm{mL})$ was used as inhibition growth positive control in the same conditions.

\section{Acknowledgments}

The authors thank the 'Région Champagne-Ardenne' and the 'Département de la Marne' for financial support. The EU-programme FEDER to the PIAneT CPER project is also gratefully acknowledged. Dominique Harakat (ICMR, UMR 7312) was also thanks to registry the MS spectra and Chantal Grimplet for the preparation of the microbial agar and liquid broths.

\section{References}

Acebey-Castellon I. L., Voutquenne-Nazabadioko, L., Doan Thi Mai, H., Roseau, N., Bouthagane, N., Muhammad, D., Le Magrex Debar, E., Gangloff, S.C., Litaudon, M., Sevenet, T., Van Hung, N., Lavaud, C., 2011. Triterpenoid saponins from Symplocos lancifolia. J. Nat. Prod. 74, 163-168

Agrawal, P.K., 1992. NMR spectroscopy in the structural elucidation of oligosaccharides and glycosides. Phytochemistry 31, 3307-30.

Baillon, H., 1876, Adansonia; recueil d'observations botaniques. Paris. 11, p 270.

Bilia, A.R., Ciampi, L., Mendez, J., Morelli, I., 1996. Phytochemical investigations of Licania genus. Flavonoids from Licania pyrifolia. Pharm. Acta Helv. 71, 199-204.

Branch, G.B., Burgess, D.V., Dunstan, P.J., Foo, L.Y.,Green, G.H., Mack, J.P.G., Ritchie, E., Taylor, W.C., 1972. Constituents of Alphitonia species. III. Alphitexolide, a new triterpene, and other extractives. Aust. J. Chem. 25, 2209-16.

Chwalek, M., Lalun, N., Bobichon, H., Ple, K., Voutquenne-Nazabadioko, L., 2006. Structureactivity relationships of some hederagenin diglycosides: haemolysis, cytotoxicity and apoptosis induction. Biochem. Biophys. Acta 1760, 1418-1427 
Clinical and Laboratory Standards Institute (CLSI). Performance Standards for Antimicrobial disk susceptibility Tests: Approved Standard M2-A7. 11 th ed. Clinical and Laboratory Standards Institute Wayne, Pa; 2005.

Connolly, J.D., Hill, R.A, 1991. Triterpenoids, in: Dey, P.M., Harborne, J.B. (serie Eds) and Charlwood, B.V., Banthorpe, D.V. (Eds), Methods in Plant Biochemistry, vol 7 Terpenoids, Academic Press, London, pp 331-359

Correa, E., Jaramillo, C., Manchester, S., Gutierrez, M., 2010. A fruit and leaves of Rhamnaceous affinities from the late Cretaceous (Maastrichtian) of Colombia. Am. J. Bot. 97, 71-79.

Dzubak, P., Hajduch, M., Vydra, D., Hustova, A., Kvasnica, M., Biedermann, D., Markova, L., Urban, M., Sarek, J., 2006. Pharmacological activities of natural triterpenoids and their therapeutic implications. Nat. Prod. Rep. 23, 394-411.

ElSohly, H.N., Danner, S., Li, X.C., Nimrod, A.C., Clark, A.M., 1999. New Antimycobacterial Saponin from Colubrina retusa. J. Nat. Prod. 62, 1341-1342.

Gossan, D.P.A., Alabdul Magid, A., Yao-Kouassi, P.A., Josse, J., Gangloff, S.C., Morjani, H., Voutquenne-Nazabadioko L., 2016. Antibacterial and cytotoxic triterpenoids from the roots of Combretum racemosum. Fitoterapia 110, 89-95

Guise, G.B., Ritchie, E., Taylor, W.C., 1962. Further constituents of Alphitonia species. Aust. J. Chem. 15, 314-321.

Guo, S., Duan, J.-A., Tang, Y., Qian, Y., Zhao, J., Qian, D., 2011. Triterpenoids from the fruits of Ziziphus jujuba var. spinosa. Biochem. System. Ecol. 39, 880-882.

Gutierrez-Lugo, M.-T., Wang, Y., Franzblau, S.G., Suarez, E., Timmermann, B.N., 2005. Antitubercular sterols from Thalia multiflora Horkel ex Koernicke. Phytother. Res. 19, 876880.

Guillaumin, A., Flore de la Nouvelle calédonie. 1948: p. 202-203.

Jou, S.J., Chen, C.H., Guh, J.H., Lee, C.N., Lee, S.S., 2004. Flavonol glycosides and cytotoxic triterpenoids from Alphitonia philippinensis. J. Chin. Chem. Soc. 51, 827-834.

Kimura, Y., Kobayashi, Y., Takeda, T., Ogihara, Y., 1981.Three new saponins from the leaves of Hovenia dulcis (Rhamnaceae). J. Chem. Soc., Perkin Trans. 1, 1923-1927.

Ko, R.K., Kim, G.O., Hyun, C.G., Jung, D.S., Lee, N.H., 2011. Compounds with Tyrosinase Inhibition, Elastase Inhibition and DPPH Radical Scavenging Activities from the Branches of Distylium racemosum Sieb. et Zucc. Phytother. Res. 25, 1451-1456.

Kennely, E.J., Lewis, W.H., Winter, R.E.K., Johnson, S., Elvin-Lewis, M., Gossling, J., 1993. Triterpenoid saponins from Gouania lupuloides. J. Nat. Prod. 56, 402-410. 
Kovganko, N.V., Kashkan, Z.N., Borisov, E.V., Batura, E.V., 2000. ${ }^{13}$ C NMR spectra of sitosterol derivatives with oxidized rings A and B. Chem. Nat. Compd. 35, 646-649.

Kubo, I., Kinst-Hori, I. 1999. Flavonols from Saffron Flower: Tyrosinase Inhibitory Activity and Inhibition Mechanism. J. Agric. Food Chem. 47, 4121-4125.

Lallemand, J.Y., Duteil, M., 1977. Carbon-13 NMR spectra of quercetin and rutin. Org. Magn. Res. 9, 179-180.

Lavaud, C., Sayagh, C., Humbert, F., Pouny, I., Delaude, C., 2015. Triterpenoid saponins from root bark of Zanha golungensis. Carb. Res., 402, 225-231

Li, D., Owen, N.L., Perera, P., Andersson, C., Bohlin, L., Cox, P.A., Pugmire, R.J., Mayne, C.L., Grant, D.M., 1994. Structure elucidation of three triterpenoid saponins from Alphitonia zizyphoides using 2D NMR techniques. J. Nat. Prod. 57, 218-224.

Li, Y.-L., Li, J., Wang, N.-L., Yao, X.-S., 2008. Flavonoids and a New Polyacetylene from Bidens parviflora Willd. Molecules 13, 1931-1941.

Lin, R.C., Bourdy, G., Lacaille-Dubois, M.A., 1995. Flavonoids from Alphitonia neocaledonica. Planta Med. 61, 197.

Lopes, J.F., Gaspar, E.M.S.M., 2008. Simultaneous chromatographic separation of enantiomers, anomers and structural isomers of some biologically relevant monosaccharides. J. Chrom. A 1188, 34-42.

Lue, B.-M., Nielsen, N.S., Jacobsen, C., Hellgren, L., Guo, Z., Xu, X., 2010. Antioxidant properties of modified rutin esters by DPPH, reducing power, iron chelation and human low density lipoprotein assays. Food Chem. 123, 221-230.

Maciuk, A., Ghedira, K., Thepenier, P., Lavaud, C., Zeches-Hanrot, M., 2003. A new flavonol glycoside from leaves of Zizyphus lotus. Pharmazie 58, 158-159.

Maciuk, A., Lavaud, C., Thepenier, P., Jacquier M.-J., Ghedira, K., Zeches-Hanrot, M., 2004. Four New Dammarane Saponins from Zizyphus lotus J. Nat. Prod. 67, 1639-1643.

McCarthy, F.O., Chopra, J., Ford, A., Hogan, S.A., Kerry, J.P., O’Brien N.M., 2005. Synthesis, isolation and characterization of $\beta$-sitosterol and $\beta$-sitosterol oxide derivatives. Org. Biomol. Chem. 3, 3059-3065.

Muhammad, D., Hubert, J., Lalun, N., Renault, J.H., Bobichon, H., Nour, M., VoutquenneNazabadioko, L., 2015. Isolation of flavonoids and triterpenoids from the fruits of Alphitonia neocaledonica and evaluation of their anti-oxidant, anti-tyrosinase and cytotoxic activities. Phytochem Anal. 26, 137-144. 
Muzitano, M.F., Tinoco, L.W., Guette, C., Kaiser, C.R., Rossi-Bergmann, B., Costa, S.S., 2006. The antileishmanial activity assessment of unusual flavonoids from Kalanchoe pinnata. Phytochemistry 67, 2071-2077.

Okamura, N., Nohara, T., Yagi, A., Nishioka, I., 1981. Studies on the Constituents of Zizyphi Fructus. III. Structures of Dammarane-type Saponins. Chem. Pharm. Bull. 29, 676-683.

Park, S.Y., Kim, J.S., Lee, S.Y., Bae, KiH., Kang Sam, S.S., 2008. Chemical constituents of Lathyrus davidii. Nat. Prod. Sc. 14, 281-288.

Parvez, S., Kang, M., Chung, H.S., Bae, H., 2007. Naturally Occuring Tyrosinase Inhibitors: Mechanism and Applications in Skin Health, Cosmetics and Agriculture Industries. Phytother. Res., 21, 805-816.

Pawlowska, A.M., Camangi, F., Bader, A., Braca, A., 2008. Flavonoids of Zizyphus jujuba L. and Zizyphus spina-christi (L.) Willd (Rhamnaceae) fruits. Food Chem. 112, 858-862.

Renault, J.-H., Ghedira, K., Thepenier, P., Lavaud, C., Zeches-Hanrot, M., Le Men-Olivier, L., 1997. Dammarane saponins from Zizyphus lotus. Phytochemistry 44, 1321-1327.

Richardson, J.E., Fay, M.F., Cronk, Q.C.B., Bowman, D., Chase, M.W., 2000. A phylogenetic analysis of Rhamnaceae using rbcL and trnL-F plastid DNA sequences. Am. J. Bot. 87, 13091324.

Schlechter, R., 1907. Beitäge zur kenntnis der Flora von Neu-Kaledonien., Leipzig: Verlag von Wilhelm Engelmann Ed. 39, p 179.

Setzer, W.N., Petty, J.L., Schmidt, J.M., Setzer, M.C., Bate, R.B., Jackes, B.R., 2004. Bioactive lupane triterpenoids in Alphitonia petriei from Paluma, north Queensland, Australia. Curr. Top. Phytochem. 6, 145-148.

Siddiqui, S., Hafeez, F., Begum, S., Siddiqui, B.S., 1988. Oleanderol, a new pentacyclic triterpene from the leaves of Nerium oleander. J. Nat. Prod. 51, 229-233.

Soicke, H., Goerler, K., Waring, H. 1990. Flavonol glycosides from Moghania faginea. Planta Med. 56, 410-12.

Wang, Y., Ding, B., Luo, D., Chen, L.-Y., Hou, Y.-L., Dai, Y., Yao, X.-S., 2013. New triterpene glycosides from Ziziphi Spinosae Semen. Fitoterapia 90,185-191.

Xu, W.-H., Jacob, M.R., Agarwal, A.K., Clark, A.M., Liang, Z.-S., Li, X.-C., 2010. entKaurane glycosides from Tricalysia okelensis. Chem. Pharm. Bull. 58, 261-264.

Yao-Kouassi, P.A., Alabdul Magid, A., Richard, B., Martinez, A., Jacquier, M.J., Caron, C., Le Magrex Debar, E., Gangloff, S. C., Coffy, A. A., Zèches-Hanrot, M., 2008. Isoflavonoid glycosides from the roots of Baphia bancoensis. J. Nat. Prod. 71, 2073-2076. 
Yoshikawa, M., Ueda, T., Muraoka, O., Aoyama, H., Matsuda, H., Shimoda, H., Yamahara J., Murakami, N., 1995. Absolute stereostructures of hovenidulciosides A1 and A2, bioactive novel triterpene glycosides from Hoveniae Semen Seu Fructus, the seeds and fruit of Hovenia dulcis Thunb. Chem. Pharm. Bull. 43, 532-534.

Yoshikawa, M., Murakami, T., Ueda, T., Matsuda, H., Yamahara, J., Murakami, N., 1996. Bioactive saponins and glycosides. IV. Four methyl-migrated 16,17-seco-dammarane triterpene glycosides from Chinese natural medicine, Hoveniae Semen Seu Fructus, the seeds and fruit of Hovenia dulcis Thunb.: absolute stereostructures and inhibitory activity on histamine release of hovenidulciosides A1, A2, B1, and B2. Chem. Pharm. Bull. 44, 1736-1743.

\section{Supporting information}

Supporting information can be found in the online version of this article. 
Figures captions :

Figure 1: structures of isolated compounds 1-19

Figure 2: Key rOe effects and HMBC correlations of ring E in compound 6

Figure 3: Key rOe effects, COSY and HMBC correlations of compound 9

Figure 4: Key rOe effects on the ring E of compounds 10 and 11 

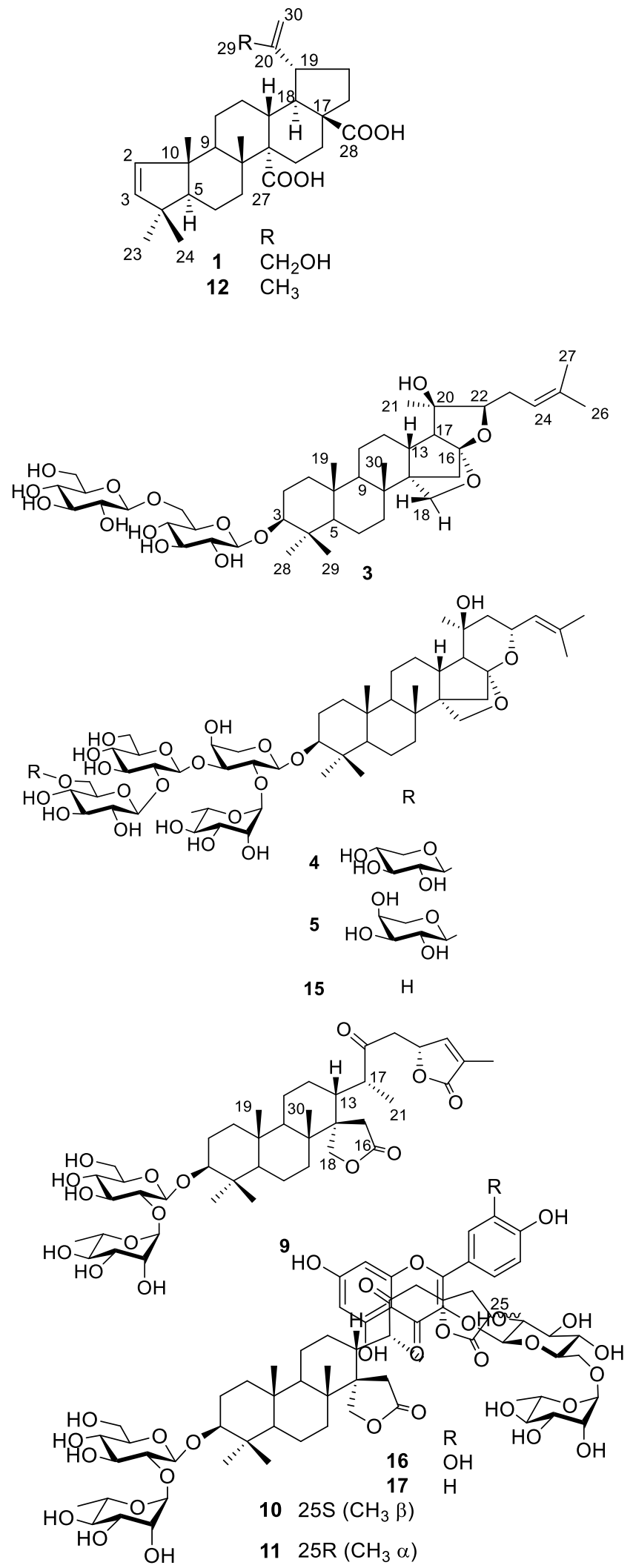

Figure 1: Structures of isolated compounds 1-19
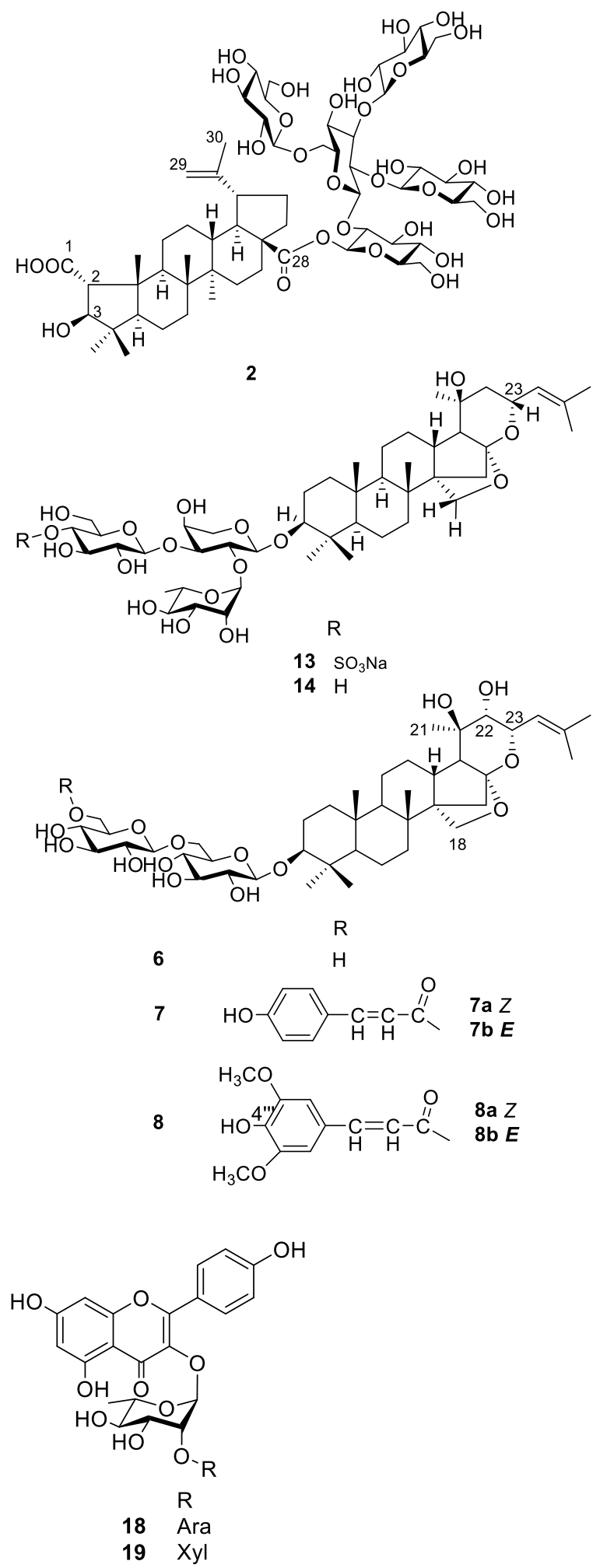

$\begin{array}{ll}18 & \text { Ara } \\ 19 & \text { Xyl }\end{array}$

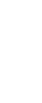




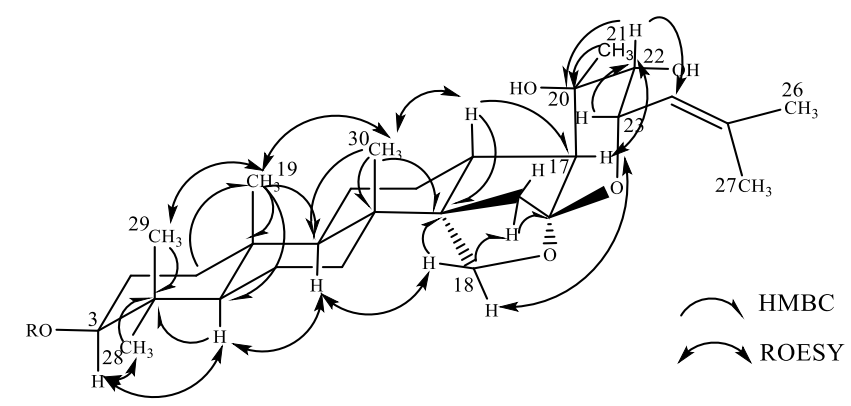

Figure 2: Key rOe effects and HMBC correlations of ring E in compound 6

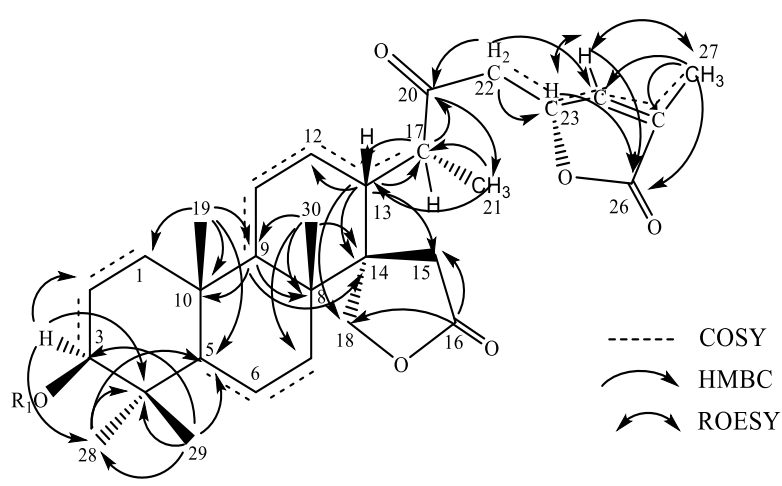

Figure 3: Key rOe effects, COSY and HMBC correlations of compound 9

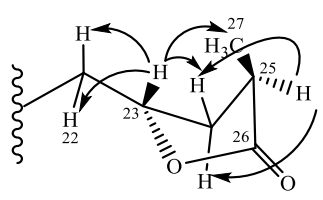

10

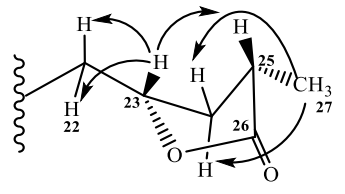

11

Figure 4: Key rOe effects on the ring E of compounds $\mathbf{1 0}$ and $\mathbf{1 1}$ 
Table 1: ${ }^{1} \mathrm{H}(500 \mathrm{MHz})$ and ${ }^{13} \mathrm{C}(125 \mathrm{MHz})$ NMR data of 2 and the osidic part of 3 in $\mathrm{CD}_{3} \mathrm{OD}$.

\begin{tabular}{|c|c|c|c|c|c|c|c|}
\hline \multicolumn{3}{|r|}{2} & \multirow{2}{*}{\multicolumn{3}{|c|}{$\begin{array}{c}\mathbf{2} \\
\delta_{\mathrm{H}}(m, J \text { in } \mathrm{Hz})\end{array}$}} & \multirow{2}{*}{\multicolumn{2}{|c|}{\begin{tabular}{|c|}
3 \\
$\delta_{H}(m, J$ in $\mathrm{Hz})$
\end{tabular}}} \\
\hline Position & $\delta \mathrm{C}$ & $\delta_{H}(m, J$ in $\mathrm{Hz})$ & & & & & \\
\hline 1 & 177.4 & - & $\mathrm{C}_{28}$-Glc & & & $\mathrm{C}_{3}$-Glc & \\
\hline 2 & 65.6 & $2.50(b r s)$ & $\mathbf{1}^{\prime}$ & 91.9 & $5.64(d, 8.3)$ & 106.7 & $4.35(d, 7.8)$ \\
\hline 3 & 84.5 & 4.10 (brs) & 2 & 75.7 & $4.07(t, 8.8)$ & 75.6 & $3.21(t, 8.5)$ \\
\hline 4 & 42.9 & - & 3' & 77.1 & $3.76(d d, 9.6,8.8)$ & 78.2 & $3.34(t, 9.1)$ \\
\hline 5 & 56.7 & $1.70(\mathrm{~m})$ & $4^{\prime}$ & 69.3 & $3.5(t, 9.6)$ & 71.7 & $3.34(\mathrm{~m})$ \\
\hline \multirow[t]{2}{*}{6} & 18.3 & $1.35(\mathrm{~m})$ & $5^{\prime}$ & 77.6 & $3.42(m)$ & 77.0 & $3.46(m)$ \\
\hline & & $1.54(m)$ & $6^{\prime}$ & 61.0 & $3.76(m)$ & 69.9 & $3.81(d d, 11.8,5.7)$ \\
\hline \multirow[t]{2}{*}{7} & 34.1 & $1.37(m)$ & & & $3.86(d d, 12.5,2.2)$ & & $4.12(d d, 11.8,2.3)$ \\
\hline & & $1.45(m)$ & $\mathrm{C}_{2}$-Glc & & & C6'-Glc $^{\prime}$ & \\
\hline 8 & 41.7 & - & $1^{\prime \prime}$ & 101.2 & $5.04(d, 7.6)$ & 104.8 & $4.42(d, 7.8)$ \\
\hline 9 & 44.4 & $1.78(d d, 12.5,2.5)$ & $2^{\prime \prime}$ & 81.3 & $3.68(m)$ & 75.2 & $3.23(t, 8.5)$ \\
\hline 10 & 49.0 & - & $3^{\prime \prime}$ & 86.6 & $3.68(m)$ & 78.0 & $3.38(t, 8.8)$ \\
\hline \multirow[t]{2}{*}{11} & 23.2 & $1.50(\mathrm{~m})$ & $4^{\prime \prime}$ & 69.6 & $3.32(m)$ & 71.6 & $3.30(t, 8.8)$ \\
\hline & & $1.59(\mathrm{~m})$ & $5 "$ & 75.7 & $3.58(d d d, 9.8,7.8,2.4)$ & 78.0 & $3.28(m)$ \\
\hline \multirow[t]{2}{*}{12} & 25.3 & $1.09(\mathrm{~m})$ & $6 "$ & 68.7 & $3.74(d d, 9.9,7.8)$ & 62.8 & $3.69(d d, 11.8,5.4)$ \\
\hline & & $1.68(m)$ & & & $4.17(d d, 10.0,2.5)$ & & $3.89(d d, 11.8,2.2)$ \\
\hline 13 & 38.3 & $2.25(t d, 11.8,3.6)$ & $\mathrm{C}_{2 "-G l c}$ & & & & \\
\hline 14 & 42.8 & - & $1^{\prime \prime \prime}$ & 103.3 & $4.71(d, 7.8)$ & & \\
\hline \multirow[t]{2}{*}{15} & 30.9 & $1.13(m)$ & $2 " '$ & 74.4 & $3.24(t, 8.2)$ & & \\
\hline & & $1.59(\mathrm{~m})$ & $3 " '$ & 76.1 & $3.40(t, 8.9)$ & & \\
\hline \multirow[t]{2}{*}{16} & 31.3 & $1.45(m)$ & $4 " '$ & 70.0 & $3.37(t, 9.0)$ & & \\
\hline & & $2.57(d m, 12.7)$ & $5 " '$ & 77.0 & $3.36(m)$ & & \\
\hline 17 & 56.7 & - & 6"' & 61.3 & $3.77(d d, 11.8,6.0)$ & & \\
\hline 18 & 49.4 & $1.65(t, 11.0)$ & & & $3.99(d, 11.8)$ & & \\
\hline 19 & 46.9 & $3.02(t d, 11.0,4.8)$ & $\mathrm{C}_{3}$ "-Glc & & & & \\
\hline 20 & 150.4 & - & $1^{\prime \prime \prime \prime}$ & 103.6 & $4.58(d, 7.8)$ & & \\
\hline \multirow[t]{2}{*}{21} & 30.2 & $1.38(m)$ & $2 " ' \prime$ & 74.0 & $3.30(t, 9.5)$ & & \\
\hline & & $1.90(t, 10.7)$ & $3^{\prime \prime \prime \prime}$ & 76.9 & $3.42(t, 9.0)$ & & \\
\hline \multirow[t]{2}{*}{22} & 36.2 & $1.50(t, 12.5)$ & $4^{\prime \prime \prime \prime}$ & 70.3 & $3.31(\mathrm{~m})$ & & \\
\hline & & $2.04(d d, 12.4,8.2)$ & $5^{\prime \prime \prime \prime}$ & 76.8 & $3.39(m)$ & & \\
\hline 23 & 30.0 & $1.10(s)$ & $6^{\prime \prime \prime \prime}$ & 61.3 & $3.64(d d, 11.9,6.7)$ & & \\
\hline 24 & 18.5 & $0.94(s)$ & & & $3.93(d d, 11.8,2.0)$ & & \\
\hline 25 & 17.9 & $1.09(s)$ & $\mathrm{C}_{6 "-\text {-Glc }}$ & & & & \\
\hline 26 & 16.4 & $1.02(s)$ & $1 " \cdots "$ & 103.6 & $4.68(d, 7.8)$ & & \\
\hline 27 & 14.0 & $1.01(s)$ & $2 " ' " '$ & 73.9 & $3.22(t, 9.0)$ & & \\
\hline 28 & 174.5 & - & $3^{\prime \prime \prime \prime \prime}$ & 76.4 & $3.49(t, 9.3)$ & & \\
\hline \multirow[t]{2}{*}{29} & 108.8 & 4.61 (brs) & $4 " ' " '$ & 70.3 & $3.31(t, 8.2)$ & & \\
\hline & & 4.73 (brs) & $5 " ' " '$ & 76.3 & $3.37(m)$ & & \\
\hline \multirow[t]{2}{*}{30} & 18.2 & $1.71(s)$ & 6"'"' & 61.4 & $3.69(d d, 9.7,5.6)$ & & \\
\hline & & & & & $3.87(d d, 11.8,2.0)$ & & \\
\hline
\end{tabular}


Table 2: ${ }^{1} \mathrm{H}$ NMR (500 MHz) and ${ }^{13} \mathrm{C}$ NMR (125 MHz) data of the genin of compounds $\mathbf{3}, 4$ and 6 in $\mathrm{CD}_{3} \mathrm{OD}$.

\begin{tabular}{|c|c|c|c|c|c|c|}
\hline \multirow[b]{2}{*}{ Position } & \multicolumn{2}{|r|}{3} & \multicolumn{2}{|r|}{4} & \multicolumn{2}{|r|}{6} \\
\hline & $\delta \mathbf{C}$ & $\delta_{\mathrm{H}}(m, J$ in $\mathrm{Hz})$ & $\delta \mathrm{C}$ & $\delta \mathrm{H}(m, J$ in $\mathrm{Hz})$ & $\delta \mathrm{C}$ & $\delta_{\mathrm{H}}(m, J$ in $\mathrm{Hz})$ \\
\hline \multirow[t]{2}{*}{1} & 38.4 & $0.99(t, 11.8)$ & 40.0 & $0.98(m)$ & 38.3 & $1.01(t d, 14.0,3.1)$ \\
\hline & - & $1.73(d d, 11.3,1.3)$ & & $1.71(b r d, 11.2)$ & - & $1.72(b r d, 13.3)$ \\
\hline \multirow[t]{2}{*}{2} & 25.8 & $1.67(t, 9.5)$ & 27.3 & $1.71(\mathrm{~m})$ & 25.8 & $1.69(\mathrm{brd}, 16.4)$ \\
\hline & - & $1.94(d d, 13.4,3,8)$ & & $1.84(d d, 14.9,5.2)$ & - & $1.95(d d, 15.3,3.7)$ \\
\hline 3 & 89.1 & $3.19(d d, 7.3,4.8)$ & 89.6 & $3.15(d d, 11.6,4.4)$ & 89.1 & $3.19(d d, 7.1,4.7)$ \\
\hline 4 & 39.0 & - & 40.5 & - & 39.0 & - \\
\hline 5 & 55.8 & $0.77(d d, 12.0,1.6)$ & 57.5 & $0.75(b r d, 11.1)$ & 55.9 & $0.78(b r d, 11.1)$ \\
\hline \multirow[t]{2}{*}{6} & 17.7 & $1.52(\mathrm{brd}, 13.3)$ & 19.1 & $1.53(\mathrm{brd}, 14.8)$ & 17.7 & $1.52(\mathrm{brd}, 11.1)$ \\
\hline & - & $1.59(t, 14.0)$ & & $1.59(t l, 10.5)$ & - & $1.58(t, 9.8)$ \\
\hline \multirow[t]{2}{*}{7} & 35.5 & $1.48(m)$ & 36.9 & $1.49(d, 11.9)$ & 35.5 & $1.46(m)$ \\
\hline & - & $1.57(m)$ & & $1.56(t l, 10.5)$ & - & $1.56(t, 10.9)$ \\
\hline 8 & 37.5 & - & 38.5 & - & 37.1 & - \\
\hline 9 & 52.3 & $0.79(d d, 13.1,2.4)$ & 54.1 & $0.90(d d, 10.0,3.9)$ & 52.7 & $0.92(d d, 11.1)$ \\
\hline 10 & 36.8 & - & 38.3 & - & 36.9 & - \\
\hline \multirow[t]{2}{*}{11} & 20.8 & $1.47(d d, 13.8,7.3)$ & 22.5 & $1.51(b r d, 12.8)$ & 21.1 & $1.49(d, 11.8)$ \\
\hline & - & $1.65(\mathrm{~m})$ & - & $1.66(d d, 12.8,2.4)$ & - & $1.69(d d, 17.3,5.3)$ \\
\hline \multirow[t]{2}{*}{12} & 26.9 & $1.67(m)$ & 29.2 & $1.71(\mathrm{~m})$ & 27.9 & $1.72(\mathrm{brd}, 16.0)$ \\
\hline & - & $1.89(\mathrm{~m})$ & - & $1.87(d, 12.8)$ & & $1.85(d d, 13.1,5.6)$ \\
\hline 13 & 36.9 & $2.43(m)$ & 38.0 & $2.51(m)$ & 36.1 & $2.55(m)$ \\
\hline 14 & 56.2 & - & 54.6 & - & 53.4 & - \\
\hline \multirow[t]{2}{*}{15} & 37.3 & $1.41(d d, 8.9,1.4)$ & 37.1 & $1.20(d, 8.6)$ & 35.6 & $1.19(d d, 8.9,1.7)$ \\
\hline & & $1.69(d, 8.9)$ & & $2.09(d d, 8.6,1.6)$ & & $2.11(d, 8.9)$ \\
\hline 16 & 117.5 & - & 111.4 & _ & 109.7 & _ \\
\hline 17 & 61.6 & $1.81(d d, 7.3,1.3)$ & 54.4 & $1.03(d d, 7.2,1.4)$ & 48.1 & $1.35(d, 8.5)$ \\
\hline \multirow[t]{2}{*}{18} & 65.4 & $3.96(d d, 8.3,1.6)$ & 66.9 & $3.97(d, 7.2)$ & 65.5 & $3.95(d, 7.0)$ \\
\hline & - & $3.99(\mathrm{~d}, 8.3)$ & & $4.05(d, 7.2)$ & - & $4.07(d, 7.0)$ \\
\hline 19 & 15.4 & $0.91(s)$ & 16.9 & $0.90(s)$ & 15.4 & $0.91(s)$ \\
\hline 20 & 75.1 & - & 69.4 & - & 70.9 & - \\
\hline 21 & 22.1 & $1.21(s)$ & 29.6 & $1.16(s)$ & 24.2 & $1.21(s)$ \\
\hline \multirow[t]{2}{*}{22} & 94.1 & $4.14(t, 6.6)$ & 45.4 & $1.40(d d, 13.8,11.1)$ & 73.8 & $3.01(s)$ \\
\hline & - & - & & $1.49(\mathrm{brd}, 10.2)$ & - & - \\
\hline 23 & 27.3 & $2.29(t l, 6.6)$ & 69.7 & $4.70(t d, 9.8,2.0)$ & 70.1 & $4.85(d, 8.4)$ \\
\hline- & - & - & - & - & - & - \\
\hline 24 & 120.7 & $5.22(t q, 7.3,0.7)$ & 126.3 & $5.18(d q, 8.3,1.4)$ & 122.1 & $5.46(d q, 8.4,1.7)$ \\
\hline 25 & 132.6 & - & 136.7 & - & 136.1 & - \\
\hline 26 & 24.5 & $1.71(s)$ & 25.8 & $1.74(s)$ & 24.5 & $1.78(\mathrm{~s})$ \\
\hline 27 & 16.5 & $1.65(s)$ & 18.4 & $1.71(s)$ & 17.1 & $1.72(\mathrm{~s})$ \\
\hline 28 & 27.0 & $1.07(s)$ & 28.5 & $1.03(s)$ & 27.0 & $1.07(\mathrm{~s})$ \\
\hline 29 & 15.5 & $0.87(s)$ & 17.1 & $0.88(s)$ & 15.5 & $0.87(\mathrm{~s})$ \\
\hline 30 & 17.8 & $1.06(s)$ & 19.2 & $1.16(s)$ & 17.8 & $1.17(s)$ \\
\hline
\end{tabular}


Table 3: ${ }^{1} \mathrm{H}(500 \mathrm{MHz})$ and ${ }^{13} \mathrm{C}(125 \mathrm{MHz}) \mathrm{NMR}$ data of the osidic part of compounds 4 and $\mathbf{5}$ in $\mathrm{CD}_{3} \mathrm{OD}$.

\begin{tabular}{|c|c|c|c|c|}
\hline & \multicolumn{2}{|r|}{4} & \multicolumn{2}{|r|}{5} \\
\hline & $\boldsymbol{\delta}_{\mathbf{C}}$ & $\delta_{H}(m, J$ en Hz $)$ & $\boldsymbol{\delta}_{\mathbf{C}}$ & $\delta_{H}(m, J$ en Hz $)$ \\
\hline \multicolumn{5}{|c|}{$\mathrm{C}_{3}$-Ara } \\
\hline $\mathbf{1}^{\prime}$ & 104.7 & $4.39(d, 6.5)$ & 104.7 & $4.39(d, 6.5)$ \\
\hline $2^{\prime}$ & 75.0 & $3.89(t, 9.4)$ & 74.7 & $3.89(t, 9.4)$ \\
\hline $3^{\prime}$ & 81.1 & $3.86(m)$ & 81.1 & $3.86(m)$ \\
\hline $4^{\prime}$ & 68.7 & $4.07(\mathrm{~m})$ & 68.7 & $4.07(m)$ \\
\hline \multirow[t]{2}{*}{$5^{\prime}$} & & $3.55(d d, 12.6,2.5)$ & & $3.55(d d, 12.6,2.5)$ \\
\hline & 64.7 & $3.87(d d, 12.6,3.4)$ & 64.7 & $3.87(d d, 12.6,3.4)$ \\
\hline \multicolumn{5}{|c|}{$\mathrm{C}_{2} \mathbf{2}^{- \text {Rha }}$} \\
\hline $1^{\prime \prime}$ & 100.8 & $5.26(d, 1.5)$ & 100.6 & $5.31(d, 1.5)$ \\
\hline $2^{\prime \prime}$ & 70.5 & $4.07(\mathrm{~m})$ & 70.5 & $4.03(\mathrm{~m})$ \\
\hline $3^{\prime \prime}$ & 70.8 & $3.73(d d, 9.1,3.5)$ & 70.8 & $3.73(d d, 9.4,2.7)$ \\
\hline $4 "$ & 72.5 & $3.43(t, 8.4)$ & 72.5 & $3.43(t, 8.4)$ \\
\hline $5 "$ & 68.7 & $3.97(m)$ & 68.7 & $3.97(m)$ \\
\hline 6" & 16.8 & $1.25(d, 6.2)$ & 16.8 & $1.25(d, 6.4)$ \\
\hline \multicolumn{5}{|c|}{$\mathrm{C}_{3}$ '-Glc } \\
\hline $1^{\prime \prime \prime}$ & 101.6 & $4.69(d, 7.8)$ & 101.6 & $4.69(d, 7.8)$ \\
\hline $2 " '$ & 80.2 & $3.70(d d, 8.6,7.8)$ & 80.1 & $3.70(d d, 8.6,7.8)$ \\
\hline 3"' & 76.9 & $3.63(t, 8.6)$ & 76.9 & $3.63(t, 8.6)$ \\
\hline $4^{\prime \prime \prime}$ & 69.8 & $3.04(t, 9.0)$ & 69.8 & $3.04(t, 9.0)$ \\
\hline $5 " '$ & 76.1 & $3.46(\mathrm{~m})$ & 76.1 & $3.46(\mathrm{~m})$ \\
\hline \multirow[t]{2}{*}{ 6"' } & & $3.68(d d, 11.8,5.4)$ & & $3.68(d d, 11.8,5.4)$ \\
\hline & 61.1 & $3.87(d d, 11.8,3.0)$ & 61.1 & $3.87(d d, 11.8,3.0)$ \\
\hline \multicolumn{5}{|c|}{$\mathrm{C}_{2 "-G l c}$} \\
\hline $1 " ' "$ & 102.7 & $4.89(d, 6.9)$ & 102.6 & $4.89(d, 6.9)$ \\
\hline $2 " ' "$ & 73.8 & $3.43(d d, 8.8,6.9)$ & 73.8 & $3.43(d d, 8.4,6.9)$ \\
\hline $3^{\prime \prime \prime \prime}$ & 76.6 & $3.38(t, 8.8)$ & 76.6 & $3.38(t, 8.8)$ \\
\hline $4 " ' \prime$ & 69.5 & $3.47(t, 8.9)$ & 69.5 & $3.47(t, 8.9)$ \\
\hline $5 " ' "$ & 75.8 & $3.46(m)$ & 75.8 & $3.46(m)$ \\
\hline \multirow[t]{2}{*}{ 6"'" } & 68.0 & $3.79(d d, 11.3,4.4)$ & 68.0 & $3.79(d d, 11.3,4.4)$ \\
\hline & & $4.16(d d, 11.3,2.7)$ & & $4.16(d d, 11.3,2.7)$ \\
\hline \multicolumn{2}{|c|}{$\mathrm{C}_{6}{ }^{\prime \prime \prime}-\mathrm{xyl}$} & & Ara & \\
\hline $1 " \cdots "$ & 104.4 & $4.34(d, 7.5)$ & 104.1 & $4.36(d, 6.8)$ \\
\hline $2 " \cdots "$ & 73.3 & $3.32(d d, 9.5,7.5)$ & 71.0 & $3.66(d d, 8.9,6.8)$ \\
\hline 3"'"' & 76.6 & $3.38(t, 9.5)$ & 72.6 & $3.61(d d, 8.9,3.4)$ \\
\hline $4 " ' " \prime$ & 69.7 & $3.53(t d, 9.5,5.5)$ & 68.3 & $3.83(\mathrm{~m})$ \\
\hline \multirow[t]{2}{*}{$5 " ' " \prime$} & 65.6 & $3.25(t, 9.9)$ & 65.5 & $3.61(d d, 9.0,3.4)$ \\
\hline & & $3.89(d d, 9.9,2.6)$ & & $3.89(d d, 9.0,2.6)$ \\
\hline
\end{tabular}


Table 4: ${ }^{1} \mathrm{H}(500 \mathrm{MHz})$ and ${ }^{13} \mathrm{C}(125 \mathrm{MHz}) \mathrm{NMR}$ data of the osidic part of compounds 6-8 in $\mathrm{CD}_{3} \mathrm{OD}$

\begin{tabular}{|c|c|c|c|c|c|c|c|c|c|c|}
\hline & 6 & & & trans -7 & & cis -7 & & trans-8 & & cis-8 \\
\hline & $\delta \mathbf{C}$ & $\begin{array}{l}\delta_{H}(m, J \text { en } \\
\text { Hz) }\end{array}$ & $\delta \mathbf{C}$ & $\delta_{\mathbf{H}}(m, J$ en Hz) & $\delta \mathrm{c}$ & $\delta_{\mathbf{H}}(m, J$ en Hz) & $\boldsymbol{\delta} \mathbf{C}$ & $\begin{array}{l}\delta_{\mathrm{H}}(m, J \text { en } \\
\mathrm{Hz})\end{array}$ & $\boldsymbol{\delta} \mathbf{C}$ & $\begin{array}{l}\delta_{\mathrm{H}}(m, J \text { en } \\
\mathrm{Hz})\end{array}$ \\
\hline \multicolumn{11}{|l|}{$\mathrm{C}_{3}$-Glc } \\
\hline $1^{\prime}$ & 105.3 & $4.35(d, 7.8)$ & 105.2 & $4.34(d, 7.8)$ & 105.1 & $4.34(d, 7.9)$ & 105.1 & $4.34(d, 7.9)$ & 105.1 & $4.34(d, 7.9)$ \\
\hline $2^{\prime}$ & 74.2 & $3.21(t, 8.1)$ & 74.1 & $3.21(d d, 9.1,7.8)$ & 74.1 & $\begin{array}{l}3.21(d d, 9.1 \\
7.9)\end{array}$ & 74.3 & $\begin{array}{l}3.21(d d, 9.0 \\
7.9)\end{array}$ & 74.3 & $\begin{array}{l}3.21(d d, 9.0 \\
7.9)\end{array}$ \\
\hline $3^{\prime}$ & 76.7 & $3.35(t, 8.3)$ & 76.7 & $3.37(t, 9.1)$ & 76.7 & $3.37(t, 9.1)$ & 76.7 & $3.37(t, 9.0)$ & 76.7 & $3.37(t, 9.0)$ \\
\hline $4^{\prime}$ & 70.1 & $3.32(t, 8.3)$ & 70.3 & $3.32(m)$ & 70.3 & $3.32(\mathrm{~m})$ & 70.3 & $3.30(t, 9.2)$ & 70.3 & $3.30(t, 9.2)$ \\
\hline $5^{\prime}$ & 75.6 & $\begin{array}{l}3.46(t d, 7.7 \\
2.2)\end{array}$ & 75.2 & $3.48(m)$ & 75.2 & $3.48(m)$ & 75.2 & $3.49(\mathrm{~m})$ & 75.2 & $3.49(\mathrm{~m})$ \\
\hline $6^{\prime}$ & 68.4 & $\begin{array}{l}3.81(d d, 11.7 \\
5.7)\end{array}$ & 68.9 & $\begin{array}{l}3.82(d d, 11.7, \\
5.8)\end{array}$ & 68.7 & $\begin{array}{l}3.80(d d, 11.7 \\
6.0)\end{array}$ & 68.7 & $\begin{array}{l}3.82(d d, 11.7 \\
5.9)\end{array}$ & 68.7 & $\begin{array}{l}3.82(d d, 11.7, \\
5.9)\end{array}$ \\
\hline & & $\begin{array}{l}4.12(d d, 11.7 \\
1.7)\end{array}$ & & $\begin{array}{l}4.09(d d, 11.7, \\
2.0)\end{array}$ & & $\begin{array}{l}4.07(d d, 11.7, \\
3.2)\end{array}$ & & $\begin{array}{l}4.09(d d, 11.7, \\
1.9)\end{array}$ & & $\begin{array}{l}4.09(d d, 11.7, \\
1.9)\end{array}$ \\
\hline \multicolumn{11}{|l|}{ C6'-Glc } \\
\hline $1 "$ & 103.4 & $4.42(d, 7.8)$ & 103.3 & $4.43(d, 7.7)$ & 103.4 & $4.40(d, 7.8)$ & 103.3 & $4.43(d, 7.8)$ & 103.3 & $4.43(d, 7.8)$ \\
\hline $2 "$ & 73.8 & $3.22(t, 8.4)$ & 73.7 & $3.25(d d, 9.0,7.7)$ & 73.7 & $\begin{array}{l}3.25(d d, 9.0 \\
7.8)\end{array}$ & 73.8 & $\begin{array}{l}3.26(d d, 9.2 \\
7.8)\end{array}$ & 73.8 & $\begin{array}{l}3.26(d d, 9.2 \\
7.8)\end{array}$ \\
\hline $3^{\prime \prime}$ & 76.6 & $3.38(t, 8.8)$ & 76.5 & $3.39(t, 9.0)$ & 76.5 & $3.39(t, 9.0)$ & 76.5 & $3.40(t, 9.2)$ & 76.5 & $3.40(t, 9.2)$ \\
\hline $4^{\prime \prime}$ & 70.2 & $3.30(t, 8.9)$ & 70.3 & $3.38(\mathrm{~m})$ & 70.3 & $3.31(\mathrm{~m})$ & 70.2 & $3.40(t, 9.2)$ & 70.2 & $3.40(t, 9.2)$ \\
\hline $5 "$ & 76.6 & $3.29(\mathrm{~m})$ & 73.9 & $m)$ & 73.9 & $3.51(\mathrm{~m})$ & 73.9 & $3.52(m)$ & 73.9 & $3.52(m)$ \\
\hline 6" & 61.4 & $\begin{array}{l}3.69(d d, 11.9 \\
5.4) \\
3.89(d d, 11.9 \\
2.1)\end{array}$ & 63.2 & $\begin{array}{l}4.29(d d, 11.9 \\
5.7) \\
4.60(d d, 11.9 \\
2.2)\end{array}$ & 63.2 & $\begin{array}{l}4.24(d d, 11.9 \\
5.8) \\
4.53(d d, 11.9 \\
2.1)\end{array}$ & 63.1 & $\begin{array}{l}4.30(d d, 11.9 \\
5.7) \\
4.61(d d, 11.9 \\
2.1)\end{array}$ & 63.4 & $\begin{array}{l}4.25(d d, 12.0, \\
6.3) \\
4.52(d d, 12.0, \\
2.2)\end{array}$ \\
\hline $\mathrm{C}_{6}{ }^{\prime \prime-}$ & & & & trans-p-coumaroyl & & cis-p-coumaroyl & & trans-sinapoyl & & cis-sinapoyl \\
\hline $1^{\prime \prime \prime}$ & & & 125.7 & - & 126.2 & - & 125.1 & - & 125.5 & \\
\hline $2^{\prime \prime \prime}$ & & & 129.9 & $7.51(d, 8.7)$ & 132.5 & $7.70(d, 8.7)$ & 105.1 & $6.98(s)$ & 108.7 & $7.33(s)$ \\
\hline $3 " \prime$ & & & 115.5 & $6.84(d, 8.7)$ & 114.6 & $6.80(d, 8.7)$ & 148.1 & - & 147.2 & - \\
\hline $4^{\prime \prime \prime}$ & & & 160.0 & - & 158.8 & - & 138.4 & - & 137.7 & - \\
\hline $5 " \prime$ & & & 115.5 & $6.84(d, 8.7)$ & 114.6 & $6.80(d, 8.7)$ & 148.1 & - & 147.2 & - \\
\hline 6"' & & & 129.9 & $7.51(d, 8.7)$ & 132.5 & $7.70(d, 8.7)$ & 105.1 & $6.98(s)$ & 108.7 & $7.33(s)$ \\
\hline$\beta-7^{\prime \prime \prime}$ & & & 145.5 & $7.68(d, 16.1)$ & 144.0 & $6.91(d, 12.8)$ & 146.0 & $7.67(d, 15.9)$ & 144.7 & $6.90(d, 13.0)$ \\
\hline$\alpha-8 " '$ & & & 113.6 & $6.40(d, 16.1)$ & 114.9 & $5.84(d, 12.8)$ & 114.3 & $6.47(d, 15.9)$ & 115.3 & $5.89(d, 13.0)$ \\
\hline 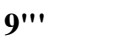 & & & 167.7 & & 166.7 & - & 167.6 & & 166.6 & - \\
\hline $\begin{array}{l}3^{\prime \prime \prime}- \\
\mathrm{OCH}_{3}\end{array}$ & & & - & - & - & - & 55.5 & $3.92(s)$ & 55.5 & $3.89(s)$ \\
\hline $\begin{array}{l}5 " \prime \prime- \\
\mathrm{OCH}_{3}\end{array}$ & & & - & - & - & - & 55.5 & $3.92(s)$ & 55.5 & $3.89(s)$ \\
\hline
\end{tabular}


Table 5: ${ }^{1} \mathrm{H}$ NMR $(500 \mathrm{MHz})$ and ${ }^{13} \mathrm{C}$ NMR $(125 \mathrm{MHz})$ data of compounds 9-11 in $\mathrm{CD}_{3} \mathrm{OD}$.

\begin{tabular}{|c|c|c|c|c|c|c|}
\hline \multirow[b]{2}{*}{ Position } & \multicolumn{2}{|r|}{9} & \multicolumn{2}{|r|}{10} & \multicolumn{2}{|r|}{11} \\
\hline & $\delta_{C}$ & $\delta_{\mathrm{H}}(m, J$ en Hz$)$ & $\delta_{C}$ & $\delta_{H}(m, J$ en Hz$)$ & $\delta_{C}$ & $\delta_{\mathrm{H}}(m, J$ en Hz$)$ \\
\hline \multirow[t]{2}{*}{1} & 38.3 & $1.02(t, 13.6)$ & 38.3 & $1.01(t d, 12.6,3.7)$ & 38.3 & $1.03(t d, 15.9,6.5)$ \\
\hline & & $1.72(b r d, 10.8)$ & & $1.72(b r d, 11.5)$ & & $1.72(b r d, 13.4)$ \\
\hline \multirow[t]{2}{*}{2} & 25.9 & $1.70(t, 14.5)$ & 25.9 & $1.69(t, 12.1)$ & 25.9 & $1.69(t, 14.2)$ \\
\hline & & $1.99(b r d, 10.7)$ & & $1.99(d d, 13.8,3.1)$ & & $1.99(d d, 14.4,4.1)$ \\
\hline 3 & 88.5 & $3.20(d d, 11.7,3.6)$ & 88.5 & $3.19(d d, 11.4,4.0)$ & 88.5 & $3.20(d d, 11.5,4.3)$ \\
\hline 4 & 38.9 & - & 38.9 & - & 38.9 & - \\
\hline 5 & 55.2 & $0.83(b r d, 14.5)$ & 55.2 & $0.83(b r d, 10.9)$ & 55.2 & $0.83(b r d, 11.6)$ \\
\hline \multirow[t]{2}{*}{6} & 17.7 & $1.55(b r d, 7.0)$ & 17.7 & $1.49(\mathrm{~m})$ & 17.7 & $1.54(d t, 12.1,3.8)$ \\
\hline & & $1.70(b r d, 14.5)$ & & $1.56(\mathrm{~m})$ & & $1.69(m)$ \\
\hline \multirow[t]{2}{*}{7} & 34.1 & $1.47(b r d, 11.3)$ & 34.2 & $1.48(d d, 15.1,7.3)$ & 34.2 & $1.47(d d, 17.3,4.6)$ \\
\hline & & $1.58(\mathrm{~m})$ & & $1.58(d d, 13.9,4.2)$ & & $1.58(d d, 9.2,3.4)$ \\
\hline 8 & 40.9 & - & 40.9 & - & 40.8 & - \\
\hline 9 & 52.6 & $0.74(b r d, 11.8)$ & 52.7 & $0.73(d d, 12.5,2.8)$ & 52.6 & $0.75(d d, 12.5,2.6)$ \\
\hline 10 & 36.5 & - & 36.5 & - & 36.5 & - \\
\hline \multirow[t]{2}{*}{11} & 20.1 & $1.52(\mathrm{~m})$ & 20.0 & $1.49(d d, 15.6,3.9)$ & 20.1 & $1.47(d d, 12.8,4.2)$ \\
\hline & & $1.62(\mathrm{~m})$ & & $1.61(\mathrm{~m})$ & & $1.63(\mathrm{brd}, 12.2)$ \\
\hline \multirow[t]{2}{*}{12} & 23.5 & $1.32(\mathrm{~m})$ & 23.6 & $1.30(\mathrm{brd}, 10.4)$ & 24.2 & $1.29(d d, 13.4,4.4)$ \\
\hline & & $1.58(\mathrm{brd}, 12.7)$ & & $1.58(b r d, 13.8)$ & & $1.67(b r d, 16.7)$ \\
\hline 13 & 37.2 & $2.43(t d, 13.0,3.5)$ & 37.3 & $2.42(t d, 13.0,3.3)$ & 37.5 & $2.48(t d, 14.2,4.4)$ \\
\hline 14 & 51.9 & - & 51.9 & - & 51.9 & - \\
\hline \multirow[t]{2}{*}{15} & 33.7 & $2.23(d, 18.8)$ & 33.8 & $2.24(d, 19.1)$ & 33.7 & $2.18(d, 19.1)$ \\
\hline & & $2.74(d, 18.8)$ & & $2.74(d, 18.9)$ & & $2.71(d, 19.0)$ \\
\hline 16 & 178.2 & - & 178.3 & - & 178.4 & - \\
\hline 17 & 45.8 & $2.61(\mathrm{~m})$ & 45.8 & $2.60(\mathrm{~m})$ & 45.9 & $2.61(m)$ \\
\hline \multirow[t]{2}{*}{18} & 70.0 & $4.39(d, 10.6)$ & 70.1 & $4.39(d, 10.6)$ & 70.3 & $4.37(d, 11.0)$ \\
\hline & & $4.49(d, 10.6)$ & & $4.49(d, 10.6)$ & & $4.49(d, 11.0)$ \\
\hline 19 & 15.1 & $0.90(s)$ & 15.1 & $0.89(s)$ & 15.2 & $0.89(s)$ \\
\hline 20 & 209.3 & - & 210.3 & - & 210.7 & - \\
\hline 21 & 10.4 & $1.07(d, 4.0)$ & 10.6 & $1.07(d, 7.5)$ & 11.6 & $1.10(d, 7.1)$ \\
\hline \multirow[t]{2}{*}{22} & 43.3 & $2.87(d, 8.6)$ & 45.2 & $2.82(d, 17.2,5.1)$ & 45.4 & $2.86(d d, 17.6,4.6)$ \\
\hline & & $2.93(d, 7.4)$ & & $3.06(d d, 17.2,8.2)$ & & $3.09(d d, 17.6,7.5)$ \\
\hline 23 & 77.8 & $5.39(m)$ & 74.8 & $5.01(\mathrm{~m})$ & 74.6 & $4.83(\mathrm{~m})$ \\
\hline \multirow[t]{2}{*}{24} & 149.6 & $7.32(d t, 6.2,1.7)$ & 34.5 & $2.14(d d, 14.3,6.4)$ & 36.2 & $1.64(b r d, 13.0)$ \\
\hline & & - & & $2.22(t d, 8.7,4.6)$ & & $2.61(d d d, 13.5,7.6,4.7)$ \\
\hline 25 & 129.4 & - & 33.7 & $2.83(\mathrm{~m})$ & 35.5 & $2.80(d d d, 13.8,6.7,5.4)$ \\
\hline 26 & 174.8 & - & 180.8 & - & 180.3 & - \\
\hline 27 & 9.1 & $1.90(b r s)$ & 14.5 & $1.27(d, 7.3)$ & 13.7 & $1.24(d, 7.3)$ \\
\hline 28 & 26.9 & $1.08(s)$ & 26.9 & $1.08(s)$ & 26.9 & $1.08(s)$ \\
\hline 29 & 15.6 & $0.88(s)$ & 15.6 & $0.88(s)$ & 15.6 & $0.88(s)$ \\
\hline 30 & 17.5 & $1.05(s)$ & 17.5 & $1.05(s)$ & 17.4 & $1.06(s)$ \\
\hline \multicolumn{7}{|l|}{$\mathrm{C}_{3}$-Glc } \\
\hline $1^{\prime}$ & 104.2 & $4.43(d, 7.6)$ & 104.2 & $4.42(d, 7.5)$ & 104.2 & $4.42(d, 7.6)$ \\
\hline 21 & 77.5 & $3.42(d d, 8.9,7.6)$ & 77.5 & $3.42(d d, 8.8,7.5)$ & 77.5 & $3.43(d d, 9.0,7.6)$ \\
\hline 3' & 78.1 & $3.48(t, 8.9)$ & 78.1 & $3.48(t, 8.8)$ & 78.1 & $3.48(t, 9.0)$ \\
\hline $4^{\prime}$ & 70.6 & $3.30(t, 9.2)$ & 70.7 & $3.31(t, 9.4)$ & 70.6 & $3.30(t, 9.1)$ \\
\hline $5^{\prime}$ & 76.3 & $3.24(\mathrm{~m})$ & 76.2 & $3.24(\mathrm{~m})$ & 76.3 & $3.24(\mathrm{~m})$ \\
\hline \multirow[t]{2}{*}{$6^{\prime}$} & 61.4 & $3.68(d d, 11.9,5.6)$ & 61.4 & $3.68(d d, 11.8,5.5)$ & 61.4 & $3.68(d d, 11.7,5.5)$ \\
\hline & & $3.86(d d, 11.9,2.2)$ & & $3.86(d d, 11.8,1.7)$ & & $3.86(d d, 11.7,2.3)$ \\
\hline \multicolumn{7}{|l|}{$\mathrm{C}_{2}$ '-Rha } \\
\hline 1" & 100.4 & $5.39(d, 1.3)$ & 100.4 & $5.39(d, 1.4)$ & 100.4 & $5.39(d, 1.8)$ \\
\hline $2^{\prime \prime}$ & 70.6 & $3.97(m)$ & 70.7 & $3.97(m)$ & 70.6 & $3.97(m)$ \\
\hline $3^{\prime \prime}$ & 70.7 & $3.76(d d, 9.5,3.4)$ & 70.8 & $3.76(d d, 9.5,3.4)$ & 70.7 & $3.76(d d, 9.6,3.3)$ \\
\hline $4^{\prime \prime}$ & 72.6 & $3.40(t, 9.6)$ & 72.6 & $3.40(t, 9.7)$ & 72.6 & $3.40(t, 9.6)$ \\
\hline $5 "$ & 68.6 & $3.99(m)$ & 68.6 & $3.99(m)$ & 68.6 & $3.99(\mathrm{~m})$ \\
\hline 6" & 16.6 & $1.23(d, 6.7)$ & 16.6 & $1.23(d, 6.1)$ & 16.6 & $1.23(d, 6.5)$ \\
\hline
\end{tabular}


Table 6: KB cells death (\%) induced by compounds 1-2, 4-6, 11-

13 and 15 at $10 \mu \mathrm{g} / \mathrm{mL}$ and $\mathrm{IC}_{50}$ of compound 12

\begin{tabular}{llll}
\hline & $\begin{array}{l}\text { cells death \% } \\
\text { at } \mathbf{1 0} \boldsymbol{\mu g} / \mathbf{m L}\end{array}$ & IC $_{\mathbf{5 0}}(\boldsymbol{\mu g} / \mathbf{m L})$ & IC $_{\mathbf{5 0}} \pm \boldsymbol{\sigma}(\boldsymbol{\mu M})$ \\
\hline $\mathbf{1}$ & 58.4 & & \\
$\mathbf{2}$ & 7.8 & & \\
$\mathbf{4 + 5}$ & 22.9 & & \\
$\mathbf{6}$ & 6.6 & & \\
$\mathbf{1 1}$ & 10.5 & $1.2 \pm 0.3$ & $2.6 \pm 0.16$ \\
$\mathbf{1 2}$ & 79.5 & & \\
$\mathbf{1 3}$ & 16.4 & & $5.5 \pm 0.11$ \\
$\mathbf{1 5}$ & 19.6 & & \\
$\boldsymbol{\alpha}$-hederin & & &
\end{tabular}


Table 7: Antimicrobial activities of compounds 1-2, 4-6, 12-15 and 20 by disc diffusion and broth diffusion methods

\begin{tabular}{lcccc|cc}
\hline \multicolumn{5}{c|}{ Inhibition zone $(\boldsymbol{\varnothing}, \mathbf{m m})$} & \multicolumn{2}{c}{ MIC $(\boldsymbol{\mu g} / \mathbf{m L})$} \\
\hline $\begin{array}{l}\text { Compounds } \\
(\mu \mathrm{g} / \mathrm{disc})\end{array}$ & S. aureus & E. faecalis & E. coli & P. aeruginosa & S. aureus & E. faecalis \\
\hline $\mathbf{1}(100)$ & 14 & 14 & - & - & 4 & 16 \\
$\mathbf{2}(500)$ & - & - & - & - & & \\
$\mathbf{4 + 5}(500)$ & - & - & - & - & & \\
$\mathbf{6}(500)$ & - & - & - & - & & \\
$\mathbf{1 2}(500)$ & 16 & 14 & - & - & & \\
$\mathbf{1 3}(500)$ & - & - & - & - & & \\
$\mathbf{1 4}(500)$ & - & - & - & - & & \\
$\mathbf{1 5}(500)$ & - & - & - & - & & \\
$\mathbf{2 0}(500)$ & - & - & - & - & & 5 \\
Gentamicin & 22 & 22 & 25 & 18 & 5 & 5
\end{tabular}

